\title{
Aerosol and ozone changes as forcing for climate evolution between 1850 and 2100
}

\author{
Sophie Szopa $\cdot$ Y. Balkanski $\cdot$ M. Schulz $\cdot$ S. Bekki $\cdot$ D. Cugnet $\cdot$ A. Fortems-Cheiney $\cdot$ \\ S. Turquety $\cdot$ A. Cozic $\cdot$ C. Déandreis $\cdot$ D. Hauglustaine $\cdot$ A. Idelkadi $\cdot$ \\ J. Lathière $\cdot$ F. Lefevre $\cdot$ M. Marchand $\cdot$ R. Vuolo $\cdot$ N. Yan $\cdot$ J.-L. Dufresne
}

Received: 26 October 2011/ Accepted: 24 May 2012/Published online: 29 July 2012

(C) The Author(s) 2012. This article is published with open access at Springerlink.com

\begin{abstract}
Global aerosol and ozone distributions and their associated radiative forcings were simulated between 1850 and 2100 following a recent historical emission dataset and under the representative concentration pathways (RCP) for the future. These simulations were used in an Earth System Model to account for the changes in both radiatively and chemically active compounds, when simulating the climate evolution. The past negative stratospheric ozone trends result in a negative climate forcing culminating at $-0.15 \mathrm{~W} \mathrm{~m}^{-2}$ in the 1990s. In the
\end{abstract}

This paper is a contribution to the special issue on the IPSL and CNRM global climate and Earth System Models, both developed in France and contributing to the 5th coupled model intercomparison project.

Electronic supplementary material The online version of this article (doi:10.1007/s00382-012-1408-y) contains supplementary material, which is available to authorized users.

S. Szopa ( $\square)$ · Y. Balkanski · M. Schulz · A. Fortems-Cheiney

A. Cozic · D. Hauglustaine - J. Lathière $\cdot$ R. Vuolo · N. Yan

Laboratoire des Sciences du Climat et de l'Environnement,

LSCE-IPSL, CEA-CNRS-UVSQ, L'Orme des Merisiers,

91191 Gif-sur-Yvette, France

e-mail: sophie.szopa@1sce.ipsl.fr

Present Address:

M. Schulz

Norwegian Meteorological Institute (MetNo), Olso, Norway

S. Bekki $\cdot$ D. Cugnet $\cdot$ F. Lefevre $\cdot$ M. Marchand

LATMOS-IPSL, UPMC-UVSQ-CNRS, Paris, France

S. Turquety $\cdot$ A. Idelkadi $\cdot$ J.-L. Dufresne

LMD-IPSL, UPMC, CNRS, ENS, Ecole Polytechnique,

Paris, France

C. Déandreis

IPSL, Paris, France meantime, the tropospheric ozone burden increase generates a positive climate forcing peaking at $0.41 \mathrm{~W} \mathrm{~m}^{-2}$. The future evolution of ozone strongly depends on the RCP scenario considered. In RCP4.5 and RCP6.0, the evolution of both stratospheric and tropospheric ozone generate relatively weak radiative forcing changes until 2060-2070 followed by a relative $30 \%$ decrease in radiative forcing by 2100 . In contrast, RCP8.5 and RCP2.6 model projections exhibit strongly different ozone radiative forcing trajectories. In the RCP2.6 scenario, both effects (stratospheric ozone, a negative forcing, and tropospheric ozone, a positive forcing) decline towards 1950 s values while they both get stronger in the RCP8.5 scenario. Over the twentieth century, the evolution of the total aerosol burden is characterized by a strong increase after World War II until the middle of the 1980s followed by a stabilization during the last decade due to the strong decrease in sulfates in OECD countries since the 1970s. The cooling effects reach their maximal values in 1980 , with -0.34 and $-0.28 \mathrm{~W} \mathrm{~m}^{-2}$ respectively for direct and indirect total radiative forcings. According to the RCP scenarios, the aerosol content, after peaking around 2010 , is projected to decline strongly and monotonically during the twenty-first century for the RCP8.5, 4.5 and 2.6 scenarios. While for RCP6.0 the decline occurs later, after peaking around 2050. As a consequence the relative importance of the total cooling effect of aerosols becomes weaker throughout the twenty-first century compared with the positive forcing of greenhouse gases. Nevertheless, both surface ozone and aerosol content show very different regional features depending on the future scenario considered. Hence, in 2050, surface ozone changes vary between -12 and +12 ppbv over Asia depending on the RCP projection, whereas the regional direct aerosol radiative forcing can locally exceed $-3 \mathrm{~W} \mathrm{~m}^{-2}$. 
Keywords Ozone - Aerosols · Radiative forcing · Climate-chemistry $\cdot$ Modeling $\cdot$ Future projections

\section{Introduction}

Reactive greenhouse gases (methane and ozone) and aerosols are key climate forcing agents, comparable to $\mathrm{CO}_{2}$ in terms of anthropogenic net radiative forcing intensity, but with contrasting regional effects. Due to the diversity of their sources and sinks, their spatio-temporal evolution is uncertain, therefore contributing to the large uncertainties in their effects on climate. Hence, the fourth assessment report (AR4) of the Intergovernmental Panel on Climate Change (IPCC) cites global average net radiative forcing due to anthropogenic changes in concentrations from preindustrial era of: $+0.48 \mathrm{~W} \mathrm{~m}^{-2}$ for methane, $+0.35 \mathrm{~W} \mathrm{~m}^{-2}$ for tropospheric ozone and $-0.05 \mathrm{~W} \mathrm{~m}^{-2}$ for stratospheric ozone. The range of uncertainty, in particular for ozone, notably exceeds the forcing estimate (these uncertainty ranges representing $90 \%$ uncertainty intervals) (IPCC 2007). The aerosol radiative forcing can be separated into three main effects: the direct effect, estimated to $-0.5 \mathrm{~W} \mathrm{~m}^{-2}$, the cloud albedo effect, estimated to be $-0.7 \mathrm{~W} \mathrm{~m}^{-2}$ and the albedo effect of black carbon on snow estimated to $+0.1 \mathrm{~W} \mathrm{~m}^{-2}$. The associated ranges around the values reaches $160 \%$ for direct effect and can reach more than double the forcing itself for the indirect effects. Altogether, these species are responsible for the dominant uncertainties in the radiative forcing evaluation (Forster et al. 2007).

Estimating the global radiative forcing is crucial to compare the various factors influencing the atmospheric energy balance. Moreover, aerosols and reactive gases also influence the Earth's climate in many other ways. For example, aerosols influence cloud lifetime and precipitation via microphysical processes (e.g. soot interactions) altering snow albedo and even inducing snow melting in particular conditions (Flanner et al. 2009; Quaas 2011); Stratospheric ozone depletion can reduce ocean carbon uptake and enhance ocean acidification (Lenton et al. 2009); Tropospheric ozone can alter the terrestrial biosphere and thus significantly modify the carbon cycle (Sitch et al. 2007). In order to investigate and quantify such effects, several groups have, during the last decade, included chemical processes into Earth System Models (ESMs) with various degrees of complexity. Hence, 23 Atmospheric Ocean General Circulation Models (AOGCMs) were involved in the previous global multi-model exercise (CMIP3) which provided the elements for the AR4-IPCC climate projections. Among these 23 AOGCMs, all but one considered the evolution of $\mathrm{CH}_{4}$, stratospheric ozone and tropospheric ozone as climate forcing. All models have taken into account the evolution of sulfate particles whereas 8 of them only dealt with the evolution of black carbon and organic carbon. Only two considered nitrates (Table 10.1 in Meehl et al. 2007). Nine models considered the indirect effects (first, second or both) of aerosols on clouds (mainly from sulfates and organic carbon). Most of the models treated the evolution of atmospheric composition as an external forcing with no online feedback of climate on atmospheric content. Furthermore, the future evolution of these compounds was ignored in some of the models due to the lack of available datasets.

In the meantime, multi-model experiments were performed with global climate-chemistry models (CCMs) and chemistry transport models (CTMs) to better assess the past and future evolution of the atmospheric composition under anthropogenic emission evolution as well as climate change: PHOTOCOMP for tropospheric chemistry (Gauss et al. 2006; Stevenson et al. 2006; Dentener et al. 2006a), CCMVal for stratospheric ozone (Eyring et al. 2005, 2006, 2007; SPARC 2010) and AeroCom for aerosols (Kinne et al. 2006; Schulz et al. 2006). Such climate-chemistry models solely consider atmospheric circulation and include a more or less detailed representation of atmospheric chemistry. The CCMs allow investigations of the effect of emissions changes on the chemical composition of the atmosphere. However, except in CCMVal, the effect of the short-lived GHG on climate was not considered in these simulations. Furthermore, the climate evolution was considered only by a few models (Gauss et al. 2006); the focus being on changes in tropospheric aerosols and ozone abundances due to emission changes.

In order to account for realistic evolution of atmospheric composition in the two French AOGCMs (IPSL-CM5, Dufresne et al. this issue and CNRM-CM5, Voldoire et al. 2012, this issue), aerosol and ozone climatologies for the period 1850-2100 were prepared using simulations from two climate-chemistry models: LMDz-OR-INCA for the tropospheric aerosols and photo-oxidative chemistry and LMDz-REPROBUS for stratospheric ozone chemistry. These models and their set-up are presented in Sects. 2.1 and 2.3. This paper aims to describe the methodology used to build these climatologies (Sect. 2.4) and to discuss the evolution of atmospheric composition therein (Sect. 4). The realism of the climatologies for present-day conditions is discussed (Sect. 3) and the radiative perturbation associated with each atmospheric forcing component is presented (Sect. 5). The way the atmospheric composition changes impact the radiative budget in the IPSL-CM5a (Low Resolution) model are discussed, keeping in mind that the previous version of this model (IPSL-CM4) solely dealt with long-lived greenhouse gases (LL-GHG: $\mathrm{CO}_{2}$, $\mathrm{CH}_{4}, \mathrm{~N}_{2} \mathrm{O}, \mathrm{CFC}$ ) and sulfates (direct and 1st indirect effect) 


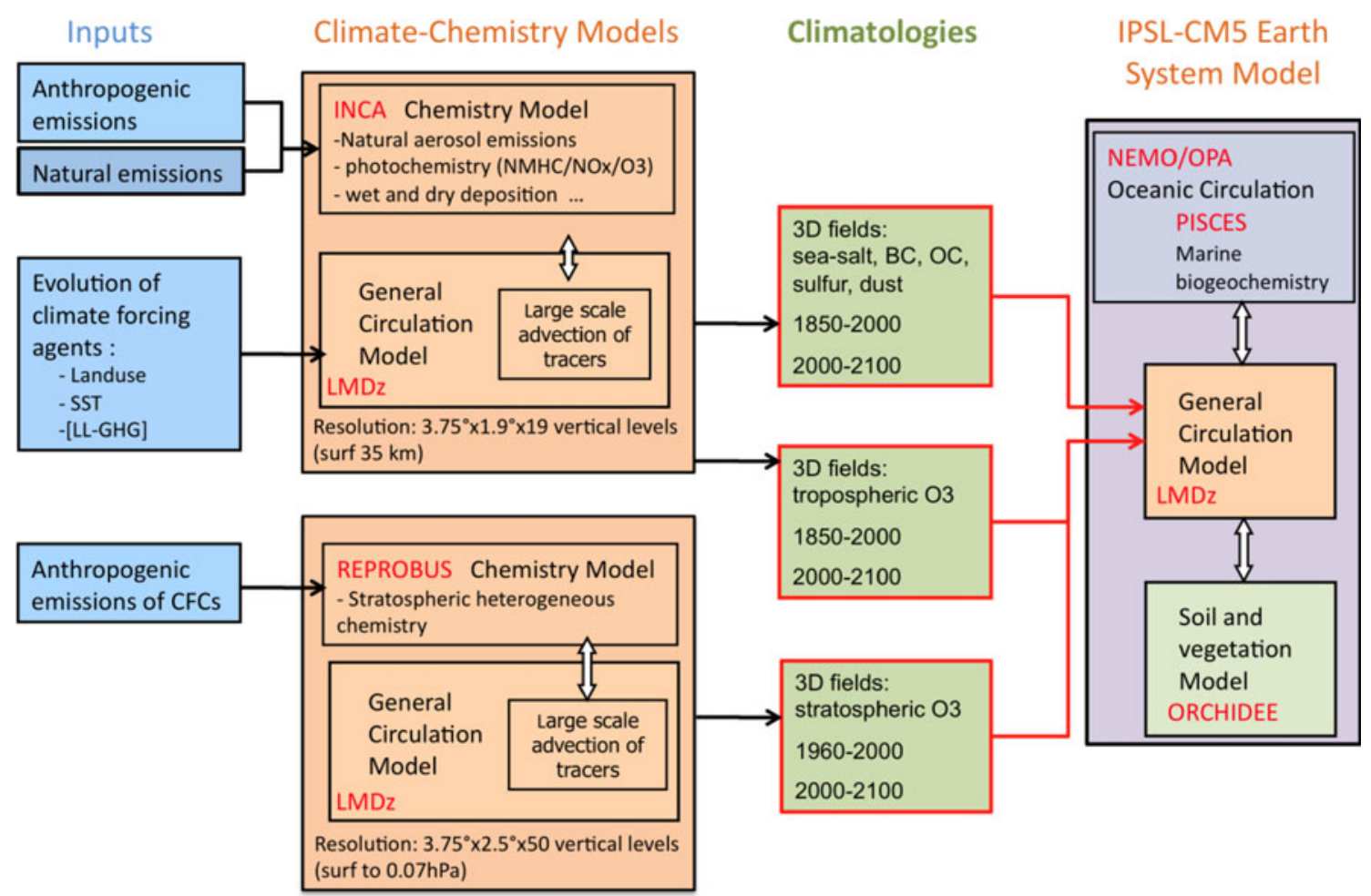

Fig. 1 Schematic of the production of ozone and aerosol climatologies prepared for the IPSL-CM5 ESM platform

for the CMIP3 multi-model exercise (Reddy et al. 2005; Marti et al. 2005).

\section{Methodology and models}

The general methodology adopted to prepare the forcing by anthropogenic reactive trace species in the atmosphere as used in the IPSL-CM5 Earth System Model is illustrated in Fig. 1. In this section, we describe the two models used to simulate the evolution of ozone and aerosols over multiple decades and their set-up. Then, we detail the way the simulated evolution of ozone and aerosols were prepared for use as climatologies in the IPSL climate simulations. Finally, we explain how chemical composition can affect the climate in the IPSL-CM5a-LR model.

\subsection{The LMDz-OR-INCA model for tropospheric chemistry modeling}

The Interaction between Chemistry and Aerosol (INCA) model is used to simulate the distribution of aerosols and gaseous reactive species in the troposphere. INCA computes primary emissions, deposition and chemical equations with a time-step of $30 \mathrm{~min}$. INCA is coupled online to the LMDz General Circulation Model (GCM) to account, with different degrees of complexity, for climate chemistry interactions. In the simulations described here, $\mathrm{LMDz}$ is coupled with the ORCHIDEE (Organizing Carbon and Hydrology in Dynamic Ecosystems) dynamic global vegetation model (Krinner et al. 2005) for soil/atmosphere exchanges of water and energy (Hourdin et al. 2006), but not for biogenic $\mathrm{CO}_{2}$ or VOC fluxes. Together, these three models form the LMDz-OR-INCA model. Fundamentals for the gas phase chemistry are presented in Hauglustaine et al. (2004) and first results with the full tropospheric gaseous chemical scheme are gathered by Folberth et al. (2006). The oxidative tropospheric photochemistry is described through 85 chemical species and 264 chemical reactions, including non-methane hydrocarbon oxidation.

For aerosols, the INCA model simulates the distribution of anthropogenic aerosols such as sulfates, black carbon (BC), particulate organic matter (POM), as well as natural aerosols such as sea-salt and dust. The aerosol code keeps track of both the number and the mass of aerosols using a modal approach to treat the size distribution, which is described by a superposition of log-normal modes (Schulz et al. 1998, Schulz 2007). The residence time of tropospheric aerosols varies from a few hours near the surface to more than 20 days in the high troposphere. The heterogeneity of the aerosol sources and the processes that they undergo in the atmosphere, make their size distribution extremely large from several nanometers to a hundred microns for dust and sea-salt. To treat the aerosol size 
diversity, particles are partitioned into 3 size classes: a submicron (diameters $<1 \mu \mathrm{m}$ ), a micron (diam. between 1 and $10 \mu \mathrm{m})$ and a super-micron class $(>10 \mu \mathrm{m}$ diam.). This treatment using modes is computationally much more efficient compared to a bin-scheme (Schulz et al. 1998). Furthermore, to account for the diversity in chemical composition, hygroscopicity, and mixing state, we distinguish between soluble and insoluble modes. In both submicron and micron-size, soluble and insoluble aerosols are treated separately. Sea-salt, $\mathrm{SO}_{4}$ and methane sulfonic acid (MSA) are treated as soluble components of the aerosol. Dust is treated as insoluble, whereas black carbon (BC) and particulate organic matter (POM) appear both in the soluble or insoluble fractions. The aging of primary insoluble carbonaceous particles transfers insoluble aerosol number and mass to soluble with a half-life of 1.1 days (Cooke and Wilson 1996; Chung and Seinfeld 2002).

The uptake and loss of water from aerosol particles is generally fast and depends on the chemical composition, size and surface properties of the aerosol particle. Aerosol water is responsible for about $50 \%$ of the global aerosol column loads. This water uptake modifies the aerosol optical properties. The nondimensional optical depth, $\tau$, can be expressed as a function of the effective radius of the aerosol:

$\tau=3 Q M / 4 \rho r_{e}$

where $Q$ is the nondimensional extinction coefficient, computed using Mie theory, $M$, is the aerosol burden per unit area $\left(\mathrm{kg} \mathrm{m}^{-2}\right), \rho$ is the particle density $\left(\mathrm{kg} \mathrm{m}^{-3}\right)$, and $r_{e}$, the effective radius (m). As relative humidity increases, this equation must be modified to account for the presence of water. The density is then recomputed as the massweighted sum of the dry density of the aerosol and the density of water. The refractive index, hence the extinction, is also changed to account for water. We use a formulation first implemented by Chin et al. (2002) to rewrite the relationship above as a function of the aerosol dry burden $M_{d r y}\left(\right.$ in $\left.\mathrm{kg} \mathrm{m}^{-2}\right)$ :

$\tau=\beta M_{d r y}$

where $\beta$, the specific extinction $\left(\mathrm{m}^{2} \mathrm{~kg}^{-1}\right)$, is computed as follows:

$\beta=3 Q M / 4 \rho r_{e} M_{d r y}$

The optical properties and hygroscopic growth of sea-salt were taken from Irshad et al. (2009). For sulfates, we followed the relationships published for ammonium sulfate by Martin et al. (2003). In the case of black carbon and organic carbon we took the same dependence of hygroscopic growth on relative humidity as Chin et al. (2002).

The aerosol scheme is thoroughly explained in Schulz (2007) and Balkanski (2011). The chemistry of ammonia/ nitrate/ammonium containing aerosols was not considered in this model version.

\subsection{LMDz-OR-INCA set-up}

The LMDz-OR-INCA simulations consist of two groups: a simulation covering the historical 1850-2000 period and a set of simulations covering four future projections of emissions for the 2000-2100 period. For the simulation aiming to represent the evolution of tropospheric composition over the past period, the emissions provided by Lamarque et al. (2010) for anthropogenic (including ship and aircraft) and biomass burning emissions are used. These emission datasets consist of fluxes for each decade of methane, carbon monoxide, nitrogen oxides and 23 nonmethane hydrocarbons (specific species or family of compounds) for ozone precursors and black carbon, organic carbon, ammonia and sulfur dioxide for aerosols and aerosol precursors. They have a $0.5^{\circ} \times 0.5^{\circ}$ horizontal resolution. For the 4 future projections, the Representative Concentration Pathways (RCP) emissions are used and can be found at [http://www.iiasa.ac.at/web-apps/tnt/RcpDb/]. They correspond to emission trajectories compatible with the evolution of radiative forcing equivalent in 2100 to 8.5 , $6.0,4.6$ and $2.6 \mathrm{~W} \mathrm{~m}^{-2}$. These scenarios are intended to span a range of climate forcing levels (Moss et al. 2010) and are not intended to be associated with any socio-economic pathway. Hence, many socio-economic pathways could potentially be associated with a given RCP scenario. Methodological elements used to build these projections can be found in Riahi et al. (2007) for RCP8.5; Fujino et al. (2006) and Hijioka et al. (2008) for RCP6.0; Clarke et al. (2007), Smith and Wigley (2006) and Thomson et al. (2011) for RCP4.5 and van Vuuren et al. (2007) for RCP2.6. An important point to mention regarding past and future emissions is the considerable effort made to reconcile the main regional and global present-day inventories to have a common starting point in 2000 for all the projections and historic reconstructions, which was not the case in previous works, for example in the IPCC-AR4 simulations (Lamarque et al. 2010). The assessment of the long-term trends induced by the use of the historical anthropogenic emission datasets in global chemical models is discussed in Lamarque et al. (2010) and is not tackled in this paper. The historical trends of total aerosols contents and global tropospheric ozone compared to those described in Cionni et al. (2011) and Lamarque et al. (2011) are shown Figures S6 and S7 of the supplementary material.

In order to use these fluxes in the INCA model, we reported the individual hydrocarbon fluxes on INCA species or surrogate species as described in Folberth et al. (2006), we spatially interpolated the fluxes to the model resolution $\left(3.75^{\circ} \times 1.9^{\circ}\right)$ and we applied a linear 
interpolation between decades. The methane oxidation is computed interactively according to the emissions and not prescribed on concentrations as often made in such exercises (e.g. Stevenson et al. 2006). The evolution of the $\mathrm{CH} 4$ concentrations simulated by LMDz-OR-INCA against those prescribed in the CMIP5 exercise is presented Figure S5 in the supplementary material. The anthropogenic and biomass-burning fluxes, compiled by Lamarque et al. (2010), are added to natural fluxes used in the INCA model. All natural emissions are kept at their present-day levels, except lightning $\mathrm{NO}_{x}$. Hence, for organic aerosols, the secondary organic matter formed from biogenic emissions is equal to that provided by the AeroCom emission dataset (Dentener et al. 2006b). The lightning $\mathrm{NO}_{x}$ emissions are computed interactively during the simulations depending on the convective clouds, according to Price and Rind (1992), with a vertical distribution based on Pickering et al. (1998) as described in Jourdain and Hauglustaine (2001). The ORCHIDEE vegetation model was used (offline) to calculate biogenic surface fluxes of isoprene, terpenes, acetone and methanol as well as NO soil emissions as described by Lathière et al. (2006). Natural emissions of dust and sea salt are computed using the $10 \mathrm{~m}$ wind components from the ECMWF reanalysis for 2006 and, consequently, have seasonal cycles, but no interannual variability. As described in Hauglustaine et al. (2004), the stratospheric ozone concentrations are relaxed toward observations at the altitudes having potential temperatures above $380 \mathrm{~K}$. The ozone observations are taken from the monthly mean 3D climatologies of $\mathrm{Li}$ and Shine (1995), based on ozone soundings and different satellite data.

The LMDz general circulation model requires sea surface temperature (SST), solar constant and LL-GHG global mean concentrations as forcings. For historical simulations, we use the HADiSST for sea surface temperature (Rayner et al. 2003) and the evolution of LL-GHG concentrations compiled in the AR4-IPCC report. For future projections, we use the LL-GHG concentrations distributed by the RCP database. No RCP projections from Earth System Model were available at that time. The SST are from previous IPSL-CM4 simulations having similar climate trajectories in terms of radiative forcing evolution. Hence, for the RCP8.5 projection, we use the SST from IPSL-CM4 simulation for the SRES-A2 scenario. Analogously, we use the SRES-A1B for RCP6.0, the SRES-B1 for RCP4.5 and the scenario E1 (van Vuuren et al. 2007) for the RCP2.6 simulation.

Using the model set-up described above, the LMDz-ORINCA is run to generate 3D monthly fields of ozone volume mixing ratio and aerosol loads (for $\mathrm{SO}_{4}, \mathrm{POM}$, SS, DUST and BC) with a $3.75 \times 1.9^{\circ}$ horizontal resolution over 19 vertical levels. In these simulations, the tropospheric composition simulated by INCA does not influence the climate simulated by LMDz-OR. The simulations were performed using a vector parallel supercomputer, NEC SX-9 system. A century-long simulation takes 3 months on four processors.

\subsection{LMDz-REPROBUS model and Set-up}

The LMDz-REPROBUS model is used to simulate the stratospheric chemistry and to produce the stratospheric ozone climatology. The REPROBUS (Reactive Processes Ruling the Ozone Budget in the Stratosphere) model (Lefevre et al. 1994, 1998) interactively calculates the global distribution of trace gases, aerosols and clouds within the stratosphere. The model has been extensively described in Jourdain et al. (2008). It includes 55 chemical species and the related stratospheric gas-phase and heterogeneous chemistry. Absorption cross-sections and kinetics data are based on the JPL recommendations (Sander et al. 2006). The photolysis rates are calculated off-line with the Tropospheric and Ultraviolet visible (TUV) radiative model (Madronich and Flocke 1998). The heterogeneous chemistry component takes into account the reactions on sulphuric acid aerosols, and liquid (ternary solution) and solid (NAT, ice) Polar Stratospheric Clouds (PSCs). The gravitational sedimentation of PSCs is also simulated.

For the calculation of the stratospheric ozone fields, REPROBUS was coupled to a version of the LMDz model, which extended from the ground up to $65 \mathrm{~km}$, on 50 hybrid sigma-pressure vertical levels, with a resolution varying in the stratosphere from about $1 \mathrm{~km}$ around the tropopause region to about 3 at $50 \mathrm{~km}$ (Lott et al. 2005). The horizontal resolution is $3.75^{\circ}$ in longitude and $2.5^{\circ}$ in latitude.

The temporal evolution of the Ozone-Depleting Substances (ODSs) and GHGs mixing ratios were derived from observations for the 1961-2006 period, and then according to one ODS scenario and two different GHG scenarios from the CCMVal project for the 2007-2100 period: REF2 and SCN-B2c (Morgenstern et al. 2010, Eyring et al. 2010b). The evolution of ODSs in REF2 is based on the scenario A1 from WMO (2007), but slightly modified to account for the earlier phase out of HCFCs agreed upon at the 2007 Meeting of the Parties to the Montreal Protocol (Morgenstern et al. 2010). Regarding GHGs, REF2 follows the SRES A1B scenario (IPCC 2001) and is close to the RCP6.0 scenario. The evolution of GHGs in SCN-B2c is fixed at 1960 levels; in comparison with REF2 results, this sensitivity scenario is used to diagnose the respective contributions of ODSs and GHGs to the evolution of stratospheric ozone. To be consistent with the evolution of GHGs, sea surface temperature and sea ice concentration (SST/SIC) in REF2 were prescribed with the AMIP (Atmospheric Model Intercomparison Project) climatologies 
for the past (Kanamitsu et al. 2002) and from results from IPSL-CM4 simulation following the SRES A1B scenario (IPCC 2007) for the future because no RCP simulations from a climate model were available yet. The SST/SIC in SCN-B2c simulation were prescribed with the 1955-1964 average of the values used in REF2.

Since the stratospheric ozone fields from REF2 follow the RCP6.0 trajectory, the construction of the fields for the three other scenarios was required to cover the range of the four RCP projections. Note that the ODS scenario is the same for all the RCP scenarios. As a consequence, the stratospheric RCP fields were reconstructed by interpolating (for RCP2.6 and RCP4.5 scenarios) or extrapolating (for RCP8.5) linearly from the REF2 and SCN-B2c stratospheric ozone series using a time-varying weighting coefficient proportional to the $\mathrm{CO}_{2}$ mixing ratio. This simple approach is supported by the finding of a nearly linear dependence of stratospheric ozone changes on the change in $\mathrm{CO}_{2}$ level over the range of RCP scenarios (Eyring et al. 2010a).

\subsection{Constructions of climatologies for use in IPSL-CM5}

Ozone variations are now considered in the IPSL-CM5 simulations, which was not the case in previous climate simulation exercises. To account for the temporal evolution of both stratospheric and tropospheric ozone, the two model-calculated ozone datasets computed respectively with the LMDz-REPROBUS and LMDz-OR-INCA models are combined in order to produce ozone fields to force the IPSL coupled ocean-atmosphere model. Tropospheric ozone fields were simulated by LMDz-OR-INCA over the 1850-2000 period and according to the four RCP scenarios for the 2000-2100 period. Stratospheric fields are based on the 1960-2100 REF-2 LMDz-REPROBUS simulation, corresponding to RCP6.0, and on inter/extrapolations between REF-2 and SCN-B2c simulations to produce the three other pseudo-RCP simulations. The choice of tropospheric and stratospheric datasets for each period is summarized in Table 1.

Atmospheric measurements and model simulations constrained by emission inventories indicate that the increase in ODS (Ozone Depleting Substances, mostly CFCs) concentrations was very marginal before 1960 (WMO 2011). Therefore, trends in stratospheric ozone are expected to be negligible before 1960 compared to post1960s stratospheric ozone changes. Therefore, prior to 1960 , only the temporal variation in tropospheric ozone is considered and a 1960s smoothed annual cycle is used for stratospheric ozone. After 1960, both tropospheric and stratospheric fields are varying. Raw monthly fields of both INCA and REPROBUS ozone time series are interpolated, zonally averaged and temporally smoothed using a 11-year running mean.

For the merging of the tropospheric and stratospheric model-calculated ozone series, the first step is to determine the chemical tropopause (defined as the contours of $150 \mathrm{ppbv}$ of ozone) in all the monthly-mean fields. Then, the INCA ozone fields are slightly stretched or compressed in the vertical in order to have the INCA tropopause altitude matching the REPROBUS tropopause altitude. Finally, REPROBUS and INCA fields are merged at the chemical tropopause region. The thickness of this transition region is taken to be about $3 \mathrm{~km}$, extending from $2 \mathrm{~km}$ above the tropopause to $1 \mathrm{~km}$ below the tropopause. The two ozone mixing ratio fields are merged within the transition region using a sinusoidal interpolation between the upper or lower limit instead of a standard linear interpolation. The resulting merged field contains INCA fields below the tropopause region and REPROBUS fields above, together with a relatively smooth transition from one field to another within the tropopause region.

There is a large diurnal cycle of ozone in the upper stratosphere and mesosphere. In order to avoid a diurnal bias in the radiative transfer calculations, notably of the heating rates, the IPSL coupled ocean-atmosphere climate model is forced by monthly-mean day-time and night-time ozone fields in this altitude range whereas it is forced with monthly-mean $24 \mathrm{~h}$ averaged ozone fields in the rest of the model domain.

Regarding aerosols, only the sulfate induced radiative forcing was considered in the previous IPSL-CM4 model (Dufresne et al. 2005). The historical evolution of sulfate was prescribed according to decadal means computed by Boucher and Pham (2002) and its future evolution was based on SRES-A2 projections (Pham et al. 2005). For the IPSL-CM5 simulations, the radiative impact of dust, sea salt, black carbon and organic carbon aerosols were introduced in LMDz as described in Déandreis (2008) and Balkanski (2011). The INCA fields are then averaged to obtain an 11-year running mean with a monthly resolution.

\subsection{The IPSL-CM5 platform for Earth system and climate modeling}

This section describes the way ozone and aerosols can influence the climate in the IPSL-CM5 platform. The solar radiation code in the LMDz GCM consists of an improved version of the parameterizations of Fouquart and Bonnel (1980). The shortwave spectrum is divided into two intervals: $0.25-0.68$ and $0.68-4.00 \mu \mathrm{m}$. The model accounts for the diurnal cycle of solar radiation and allows fractional cloudiness to form in a grid box. The reflectivity and transmissivity of a layer are computed using the delta Eddington approximation (Joseph et al. 1996) in the case of 


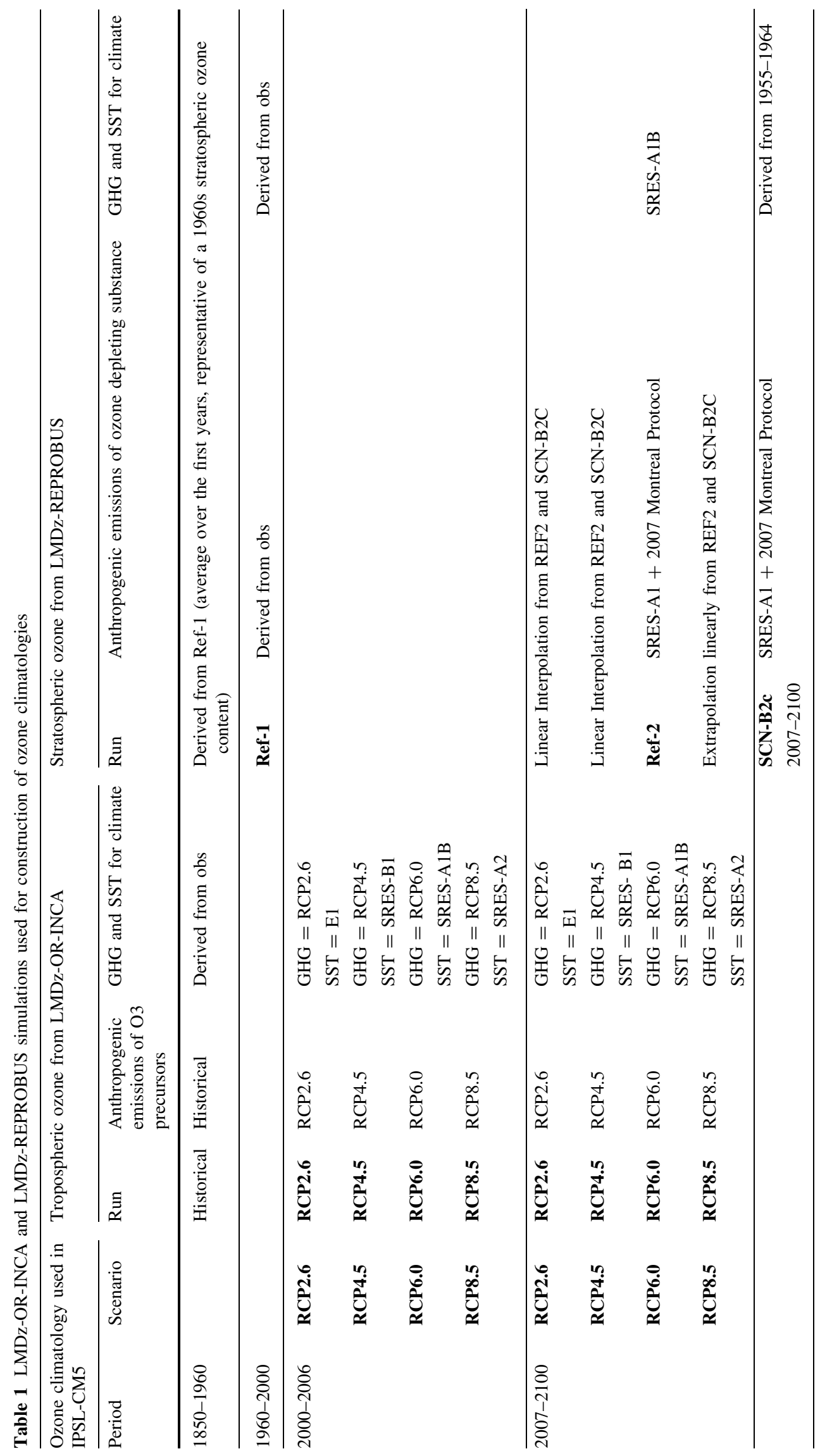


a maximum random overlap (Morcrette and Fouquart 1986) by averaging the clear and cloudy sky fluxes weighted linearly by their respective fractions in the layer. The radiative fluxes are computed every $2 \mathrm{~h}$, at the top-ofatmosphere and at the surface, with and without the presence of clouds, and with and without the presence of aerosols. The clear-sky and all-sky radiative effect of aerosol components or greenhouse gases is finally obtained by subtracting from the radiative fluxes the radiative effect of the respective in 1850 components. For ozone, the averaged day-night ozone is used for longwave whereas only daylight ozone is used for shortwave computations. Regarding aerosols, we treat the indirect effect of aerosols by computing the first indirect effect only. For this effect, the cloud droplet number is increased with aerosol concentrations for constant liquid water content. We do not consider the second indirect effect that affects the lifetime of clouds. The number of cloud droplets is calculated through the prognostic equation from Boucher and Lohmann (1995), with the coefficients that were derived from the Polder satellite measurements by Quaas and Boucher (2005). The cloud droplet number concentration (CDNC, in droplets per $\mathrm{cm}^{3}$ ), is computed from the mass of soluble aerosol $\mathrm{m}_{\text {soluble }}=\mathrm{m}_{\mathrm{SO} 4}+\mathrm{m}_{\mathrm{BC}}$, soluble $+\mathrm{m}_{\mathrm{POM} \text {, soluble, }}$ through the relationship:

$\mathrm{CDNC}=10^{1.7+0.2 \log \left(\mathrm{m}_{\text {soluble }}\right)}$

considering the parameters described in Dufresne et al. (2005) and mass (m) in $\mu \mathrm{g} \mathrm{m}^{-3}$.

\section{Present-day distribution of aerosols and ozone}

In this section we discuss briefly the realism of the present day distribution of the reactive climate forcing agents. Since the simulations are performed with a GCM climate (as opposed to using a CTM or a nudged climate), the comparison of model results with observations is only meaningful when considering observations sufficiently averaged in time to have a climatological representativity. It would not make sense to attempt to collocate model results and observations as is done for a full model evaluation. Moreover, the evaluation of the successive versions of LMDz-INCA (used in nudged mode) and LMDz-REPROBUS, particularly in the framework of international modeling exercises (see references in Sect. 1), gives us confidence in their capabilities to reproduce ozone and aerosol distributions and their evolution. However, as with the other global chemical-climate models (Shindell et al. 2003; Lamarque et al. 2011 and references therein), LMDz-OR-INCA failed to reproduce the $\leq 10 \mathrm{ppb}$ values of ozone measured in the late nineteenth century.

\subsection{Tropospheric composition}

The LMDz-INCA model results have been extensively evaluated with surface, aircraft, and satellite observations of tropospheric oxidants, aerosols, and related species and the conformity of the results of this GCM version compared with the CTM results has been checked (not shown). Regarding tropospheric ozone, the LMDz-INCA chemical results were compared with many other global CTMs or GCMs, and with observations as part of the international HTAP (Hemispheric Transport of Air Pollution) and ACCENT/PhotoComp (Atmospheric Composition Change: the European NeTwork of excellence) exercises. The related papers show a response (in terms of sensitivity to emissions) of LMDz-INCA which is quite similar to the ensemble mean of the results for ozone (Stevenson et al. 2006). Comparisons with ozone surface network (Ellingsen et al. 2008) show a systematic positive bias for all the models, partly due to misrepresentation of $\mathrm{NO}_{x}$ gradients close to the sources. Reidmiller et al. (2009) and Fiore et al. (2009) tried to discriminate the climatologic features of ozone measured by the CASTNET (Clean Air Status and Trends Network; USA) and EMEP (European Monitoring and Evaluation Programme) networks before comparing with global models. LMDz-INCA showed in these studies a fairly good agreement for ozone with US stations.

Figure 2 shows the monthly zonal-mean distribution of tropospheric ozone in the INCA_REPROBUS climatology (11-year mean around 2007) and for two remote sensing based datasets: the NASA-TES dataset (averaged over the 2006-2008 period) and the IASI dataset (averaged over the 2008-2010 period). TES (Tropospheric Emissions Spectrometer) is an infrared spectrometer flying aboard the Aura satellite, the third of NASA's Earth Observing System (EOS) spacecraft, which has orbited Earth since 2004. This high resolution Fourier transform spectrometer, has been flying on a $\sim 705 \mathrm{~km}$ sun-synchronous polar orbit, with equator crossing time about 13:43 LST. It provides global ozone measurements, retrieved from the $9.6 \mu \mathrm{m}$ ozone absorption band using the $995-1,070 \mathrm{~cm}^{-1}$ spectral range. The present study makes use of the TES Version 004 nadir ozone profiles (level 2), collected from https://wist.echo.nasa.gov/. These profiles are reported on a vertical grid of 67 standard levels (surface +66 levels). The retrievals and error estimation, already described by Worden et al. (2004), Bowman et al. (2002, 2006) and Kulawik et al. (2006) are based on the optimal estimation approach (Rodgers et al. 2000). TES ozone has been evaluated on a regular basis since the start of the mission in 2004, and compared against ozone-sonde measurements. For the previous version, Nassar et al. (2008) indicate a positive bias comprised in the $3-10 \mathrm{ppbv}$ range for the upper-troposphere and lower-stratosphere. For the most 


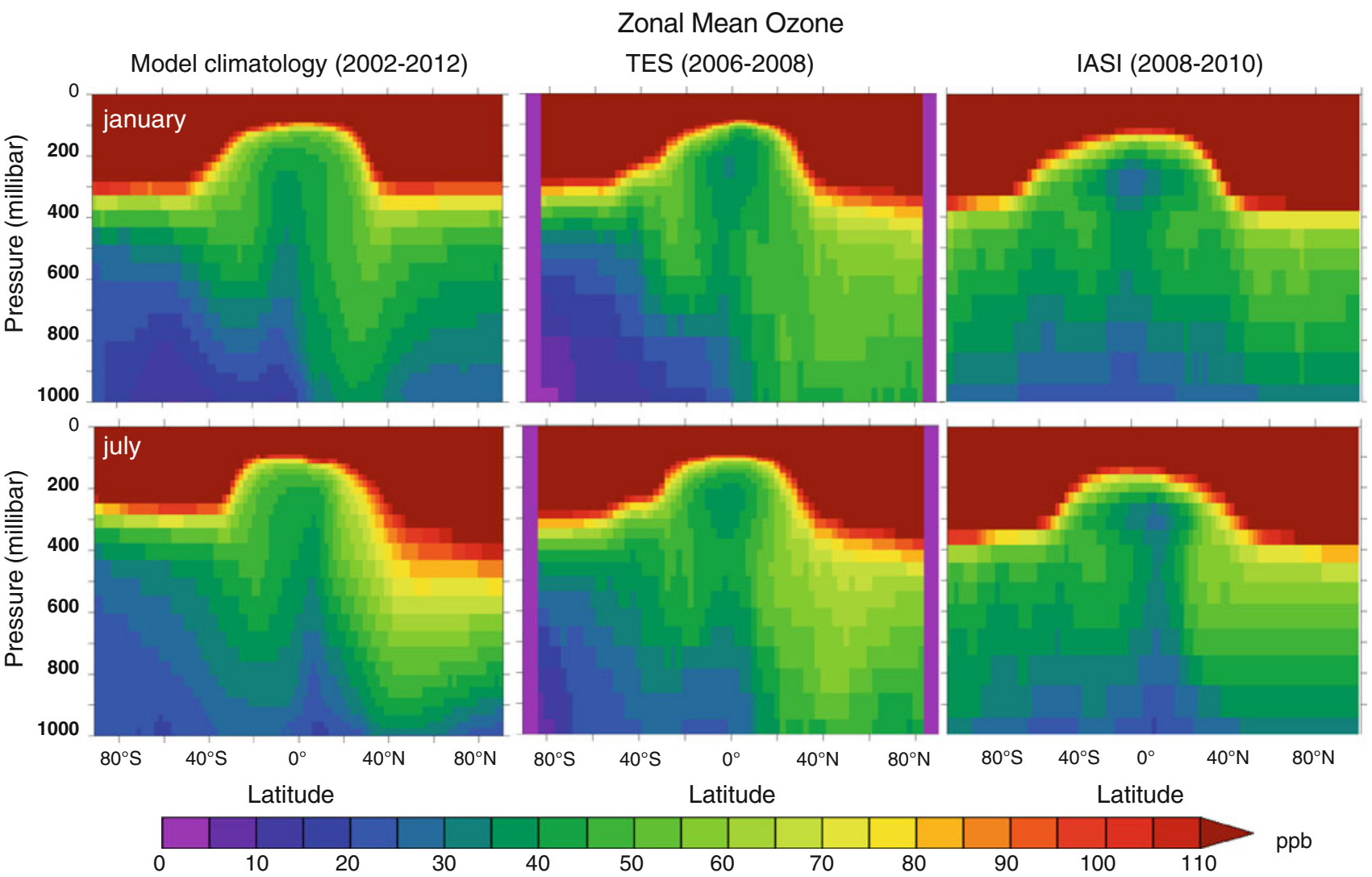

Fig. 2 Monthly averaged zonal-mean ozone distribution in ppbv. The model results (left column) are averaged over a 11 year period centered around 2007. The remote sensing based ozone is obtained using the TES dataset averaged over the 2006-2008 period (middle column) and using the IASI dataset over the 2008-2010 period (right column)

recent versions, Boxe et al. (2010) indicate, for the high latitudes, a positive bias from the surface to the uppertroposphere, and a negative bias from the upper-troposphere to the lower-stratosphere. The data have been selected following the criteria of the TES v004 Data Users's Guide (http://tes.jpl.nasa.gov/documents/, access: September 2011) and of quality flags (SpeciesRetrievalQuality flag $=1$, Ozone "C-Curve" flag =1) developed by the data providers.

The ozone retrievals from the nadir-viewing Infrared Atmospheric Sounding Instrument (IASI), launched onboard the polar-orbiting METOP platform in December 2006, are also shown. TES and IASI are both nadir-viewing Fourier Transform spectrometers, such that both datasets have similar characteristics. The main differences are: IASI has better horizontal coverage (twice daily global coverage while TES has a 10 days revisit time), but TES has better spectral resolution $\left(0.1 \mathrm{~cm}^{-1}\right.$ for TES and $0.5 \mathrm{~cm}^{-1}$ for IASI). The latter results in better vertical resolution for TES, with $\sim 4$ independent pieces of information in the vertical, two of which are in the troposphere, compared to $\sim 3$ for IASI. This vertical resolution directly depends on surface temperatures, with more information above warm surfaces. The IASI retrievals used in this work are from the FORLI algorithm, which is also based on optimal estimation. A full description of the retrieval method and setup is provided in Coheur et al. (2005) and Boynard et al. (2009). The validation against ozone sondes in the mid and tropical latitudes performed by Boynard et al. (2009), Keim et al. (2009) and Dufour et al. (2011) shows good agreement in terms of tropospheric partial columns. They all note, however, a tendency to overestimate ozone, especially in the tropopause region. The UTLS bias (12\%) is partly compensated by a low bias in the lower troposphere $(-7 \%)$. The observed biases in the UTLS are most likely linked to the instrumental limitations in terms of vertical sensitivity (large correlations between vertical levels). Information on the troposphere will be particularly limited above cold surfaces, so that the performance is expected to be lower in polar regions (low sensitivity to the lower troposphere, lower tropopause). Here, a monthly-mean climatology based on the retrievals in 2008 to 2010 has been constructed using filters based on retrieval errors recommended by the retrieval team (D. Hurtmans, personal communication) to keep only the most accurate data. An accurate, quantitative, comparison between model and 
observations would require that each instrument's vertical sensitivity characteristics be taken into account (i.e. the calculation of model profiles smoothed with the averaging kernels). Since precise validation was not the purpose here, only a simple, direct comparison was undertaken.

Comparing with TES data, the ozone mixing ratios are satisfactorily well reproduced by the climatology with values of a few tens ppbv at the surface increasing with altitude and a North/South gradient due to the distribution of emissions. The northern free tropospheric values are slightly underestimated by the model with differences of 10-25 ppbv at $500 \mathrm{hPa}$ at northern midlatitudes. Elsewhere in the troposphere the underestimation is lower than $10 \mathrm{ppbv}$. An overestimation appears in the upper troposphere $(P<400 \mathrm{hPa})$ at the Southern mid latitudes $\left(30^{\circ} \mathrm{S}: 60^{\circ} \mathrm{S}\right)$ but not exceeding $20 \mathrm{ppbv}$. Such differences between the model results and the TES data are partly explained by the TES bias found by Nassar et al. (2008) and Boxe et al. (2010) and are in the lower range of those reported for four state-of-the-art global chemistry climate models in Aghedo et al. (2011). For IASI, direct comparison is trickier due to the coarser vertical resolution, and would require comparisons of integrated columns. It is interesting to note, however, that the discrepancies between TES and the model-based climatology remain lower than the differences between two similar satellite sensors.

In order to quantify the potential impact of the model/ TES discrepancies on the evaluation of radiative forcing of ozone, Aghedo et al. (2011) defined the instantaneous radiative forcing kernels (IRFK). The IRFK represent the sensitivity of outgoing longwave radiation to the vertical and spatial distribution of ozone under all-sky conditions. This sensitivity reaches its maximum in the tropical free troposphere (between 550 and $300 \mathrm{hPa}$ ) with values reaching $0.6-0.8 \mathrm{~mW} \mathrm{~m}^{-2} \mathrm{ppbv}^{-1}$. It means that a $10 \mathrm{ppbv}$ systematic underestimation could lead, locally, to a $0.07 \mathrm{~W} \mathrm{~m}^{-2}$ underestimation of the radiative forcing according to Aghedo et al. (2011). In this particularly sensitive region of the troposphere, the mean difference between the climatology and TES is $-3.2 \mathrm{ppbv}$ (i.e. $\sim 5-10 \%$ of the absolute global value) leading to a possible underestimation of $0.024 \mathrm{~W} \mathrm{~m}^{-2}$ of the radiative forcing.

The aerosol optical depth (AOD) contains contributions from the different aerosol species. Total AOD is often used to evaluate aerosol simulations because of the availability of global observational datasets e.g. from Aeronet. The split of AOD into contributions from aerosol species is of interest, for example to attribute radiative forcing to scattering and absorbing aerosols. We first evaluate, for each aerosol type, the LMDz-OR-INCA results for the year 2000 compared with the AeroCom multi-model ensemble from phase I (Textor et al. 2006), representing year 2000,
Total Aerosol and Species Optical Depth

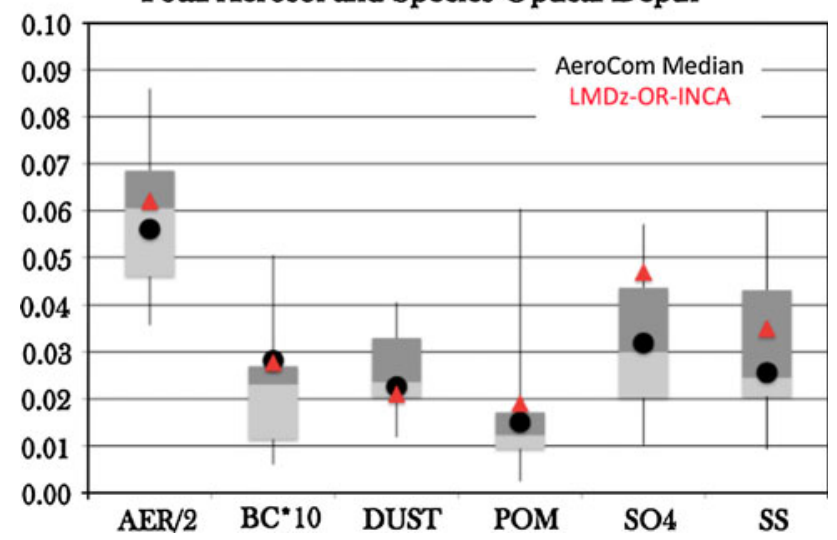

Fig. 3 Optical Depth of the INCA model (red triangles) for total aerosol and the aerosol species against the AeroCom phase I model median (black dots). The spread of recent AeroCom phase II results is shown as box and whisker plot with minimum, $25 \%$ percentile, median, $75 \%$ percentile and maximum. Note that total AOD is scaled by a factor 0.5 and Black Carbon OD by 10

and the range of model results from the AeroCom phase II, representing the year 2006 (see Fig. 3). Considering that the emissions are different, the LMDz-OR-INCA results are close to the AeroCom database (i.e. within 25-75\% percentile distribution of model results) for black carbon, dust, sea-salts and total aerosol. The POM optical depth is slightly higher than the mean. The $\mathrm{SO}_{4}$ content is outside the $25-75 \%$ percentile interval with a $50 \%$ overestimation of the total content compared with the median value. Compared with the results from the CAM-CHEM model using the same emissions (Lamarque et al. 2010), the black carbon burdens are identical both in 1850 and 2000, the sulfate burden is $15 \%$ lower in INCA for the 2000 year and the burden of particulate organic matter is $80 \%$ higher in INCA but at least $2 / 3$ of this discrepancy arises from the consideration of secondary organic aerosol from natural sources in the POM category. Altogether total AOD is close to the median from current models used for the AeroCom phase II. For each species, the spatial concordance between these INCA results and the AeroCom median can be checked Figures S2, S3 and S4 of the supplementary material. The order of magnitude of the maxima and their location are captured (keeping in mind that the years are not the same and that interannual variability is large for species with natural sources).

We secondly evaluate the AOD fields against observations. Given we read in the aerosol mass fields from LMDz-OR-INCA into the IPSL-CM5a-LR, the final AOD affecting the climate model runs differs slightly because of humidity fluctuations and synoptic variations (different in the two model versions). We thus chose to evaluate both the LMDz-OR-INCA field for year 2000 and the decadal mean for 2000-2009 from the IPSL-CM5a-LR historical 

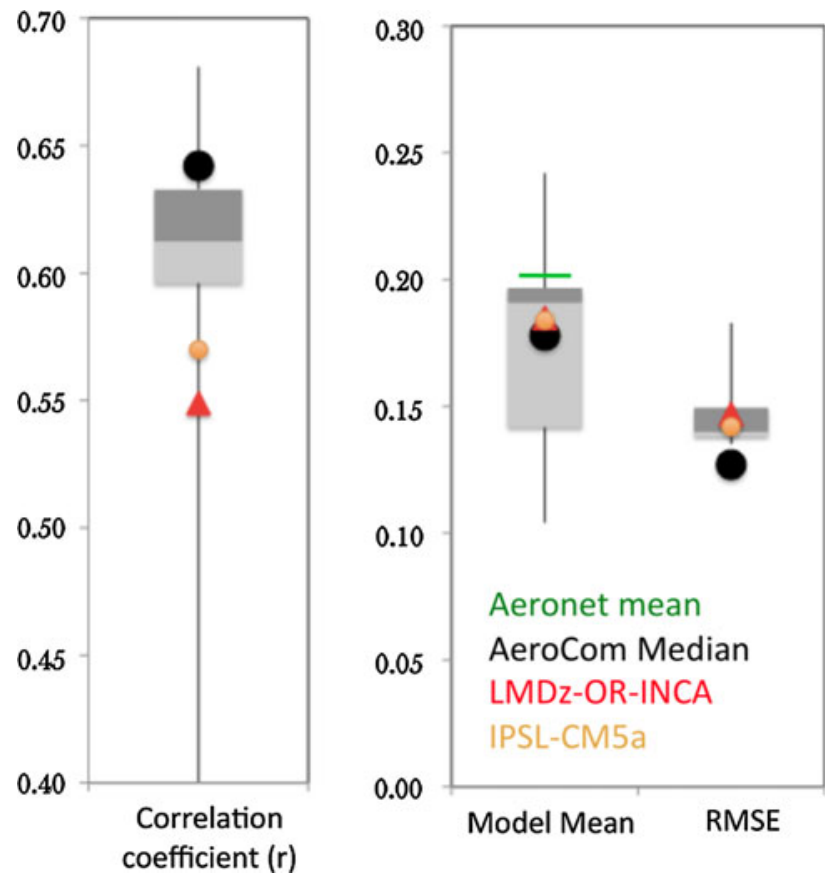

Fig. 4 Statistics of evaluation of aerosol optical depth of the INCA model and the IPSL-CM5a evaluation against monthly worldwide Aeronet data climatological mean 2000-2009. Correlation coefficient, model mean at Aeronet sites (Observations show mean of 0.202) and RMS error are shown. For comparison, AeroCom phase II model median is also shown (black dots). The spread of corresponding recent AeroCom phase II results is shown as box and whisker plot with minimum, $25 \%$ percentile, median, $75 \%$ percentile and maximum

base run against a climatological dataset constructed from Aeronet sun photometer data covering 2000-2009 (Schulz and Aerocom team 2011). Figure 4 shows the basic statistics of monthly aggregated data at the Aeronet surface sites for these two model results. The same statistics are obtained for representative AeroCom model results, range and median of the models. The AeroCom ensemble multimodel mean outperforms most models. The INCA and IPSL show slightly lower correlation with observed AOD than the recent AeroCom phase II results. However, these latter have specifically used 2006 meteorology and emissions representative of the last part of the decade. In terms of RMS errors, the models are rather similar. At the Aeronet sites the mean AOD of the LMDz-OR-INCA model is close to the median of the recent state-of-the-art multimodel ensemble. The performance of the IPSL-CM5a-LR AOD field is slightly better than the LMDz-OR-INCA forcing model AOD field. This might reflect the fact that we use the decadal mean of the whole decade from the IPSL climate model run, and only the year 2000 from the INCA model run. All in all it shows the realism of the AOD fields used in the IPSL-CM5 model (see also figure $\mathrm{S} 1$ in the supplementary material).

\subsection{Stratospheric ozone}

The LMDz-REPROBUS model simulations of stratospheric ozone used to build the climatologies for the IPSLCM5 for the 1850-2006 period have been evaluated against other chemistry-climate models and a wide range of observations (Jourdain et al. 2008; Austin et al. 2010a, b; Gettelman et al. 2009a, b; Hegglin et al. 2010; Morgenstern et al. 2010). Figure 5 shows a comparison between the model-calculated and the HALOE (Halogen Occultation Experiment) observation-based annual zonal mean distributions. The model-calculated distribution reproduces correctly the maximum of about $10 \mathrm{ppmv}$ near $10 \mathrm{hPa}$ in the tropics but the model-calculated maximum is a bit narrower than in the HALOE climatology. In the stratosphere, the difference in ozone mixing ratios between the model-calculated climatology and the HALOE climatology is generally within $0.5 \mathrm{ppmv}$, except at high latitudes in the upper stratosphere due to shortcomings in the transport in the LMDz-REPROBUS model (Jourdain et al. 2008). In the mesosphere (above $1 \mathrm{mb}$ level), the ozone mixing ratio is overestimated compared to HALOE observations which is not surprising since the model chemistry scheme is only suited for stratospheric applications.

\section{Atmospheric composition change between 1850 and 2100}

\subsection{Ozone}

When analysing total column ozone changes, one has to keep in mind that about $90 \%$ of the ozone is contained in the stratosphere. Therefore, total column ozone changes are generally driven by stratospheric ozone changes. Figure 6 (upper panel) shows the evolution of the model-calculated globally and annually averaged total column ozone for the four scenarios since 1960 only. Figure 7 shows the evolution of annually averaged total column ozone as a function of latitude for the standard scenario RCP6.0. Before 2010, the model-calculated column ozone changes reproduce all the major features of the long-term temporal evolution of column ozone revealed by observations, mostly satellite, balloon, and ground-based. On a global scale, the model-calculated total column ozone decreases by about $4 \%$ from 1960s to the end of the 1990s with most of the reduction occurring primarily at mid- to high latitudes of both hemispheres. There is no clear trend in the tropics. All theses features in the model-calculated column ozone climatology are in line with the trends reported from observations (WMO 2011; SPARC 2010). In view of the well-established impact of the so-called ozone hole on the Antarctic climate (Son et al. 2010), it is important that the 
Fig. 5 Annual zonal-mean ozone distribution (in ppm) based on (1) the LMDz-INCAREPROBUS climatology for the 1992-2002 (left panel) and (2) the HALOE observation dataset for the 1991-2002 period (right panel)

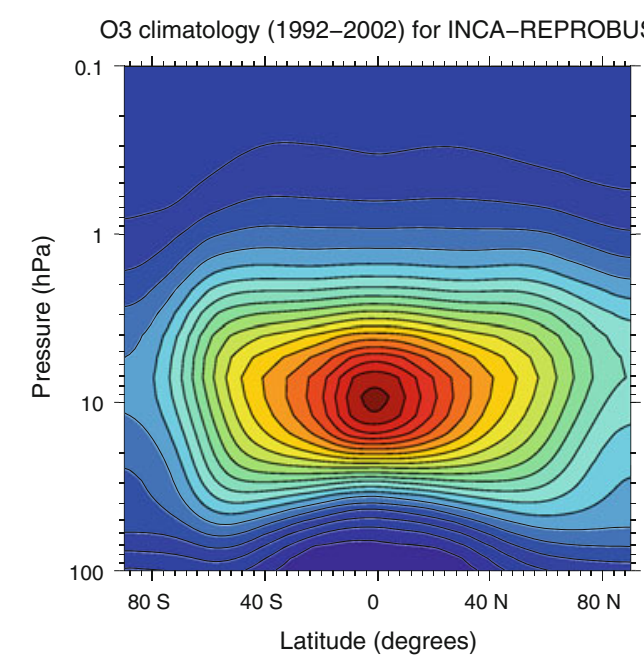

model-calculated time-varying ozone climatology reproduces as well as possible this phenomenon. In agreement with observations, the LMDz model reproduces the rapid and continuous decline in total column ozone observed every spring above Antarctica since 1970s (see Fig. 7). The ozone hole tends to be slightly deeper than in the observations, but the trend in the date of the Antarctic ozone minimum agrees with the trend derived from observations. A range of comparisons with observations and with other chemistry-climate models have shown that LMDz provides a realistic simulation of the Antarctic stratospheric ozone changes between the decades of the 1970s and the beginning of the 2000s, and agree reasonably well with observations (Austin et al. 2010b).

After 2006, the ozone trajectories of the different scenarios start to diverge. The ODS evolution being the same in all the scenarios, the divergence is due to the differences in the specified GHG evolution. Up to present day, the rapid increase in the stratospheric halogen loading has been the dominant driver of ozone changes. However, the increase in GHG levels is expected to become an important driver in the future because of the slow decline in ODS levels. Stratospheric halogen loading has peaked at the end of the last century and is now slowly diminishing at a rate primarily controlled by the atmospheric lifetimes of individual chlorine and bromine gases. In the model-calculated climatologies, the maximum total ozone depletion occurs at the end of 1990s, somewhat coincident with the peak in stratospheric halogen loading. Thereafter, total column ozone is projected to increase in all the scenarios, except in the tropics (Fig. 7). Total column ozone recovers the 1960s levels before or by midcentury at mid-latitudes, which is earlier than expected from the decline in stratospheric halogen loading. In the last half of the century, total column ozone increases, then exceeds the 1960 levels. This behavior, called the ozone super-recovery, is primarily resulting from the GHG-induced cooling of the upper stratosphere (which slows down the ozone destruction) and from the GHG-induced acceleration of the Brewer-Dobson circulation (which enhances the column ozone at mid and high latitudes). The rate of ozone recovery varies with the scenario considered. At mid-latitudes, the return time of total column ozone to, for example, 1980 values varies by up to 10 years among the GHG scenarios, while the difference can reach 15-20 years at high latitudes. Antarctic total ozone is projected to return to 1980 levels well after mid-century. That is later than in any other regions in all the scenarios, suggesting that the effect of GHG-driven climate change on ozone is smaller in the Antarctic region than in other regions. In contrast, total column ozone remains below 1960 values in the tropics throughout the century, due to GHG-driven increased tropical upwelling in all GHG scenarios (Eyring et al. 2010a, b) as can be seen Figure S8 in the supplementary material.

Figure 6 (middle and lower panels) also depicts the evolution of the global tropospheric ozone content at the surface as well as for tropospheric burden. Over the historical period (1850-2000), three sub-periods can be distinguished: the 1850-1950 period characterized by a slight constant increase of ozone of about $0.03 \mathrm{ppbv} / \mathrm{year}$ for surface ozone (and $0.3 \mathrm{Tg} / \mathrm{year}$ increase of the burden), the $1950-1990$ period is characterized by a strong and steady increase of ozone of $\sim 0.06 \mathrm{ppbv} /$ year and $0.5 \mathrm{Tg} /$ year for surface ozone and burden respectively and the 1990-2000 is a period during which the ozone remains almost unchanged. Starting with the year 2000, the four trajectories correspond to the four RCP emission scenarios. They start to differ significantly (considering global mean) from 2010 onwards. Then the RCP8.5 emission projection leads to a significant increase of the ozone burden $(+30 \mathrm{Tg}$ from 2010 to 2100), mainly due to the increase from 2010 to 2070. Moreover, the global surface ozone increases until 2070 in this scenario (reaching up to $27.6 \mathrm{ppbv}$ ) and then shows a slight decrease. At the global scale, however, all 
Total ozone (Dobson Unit)
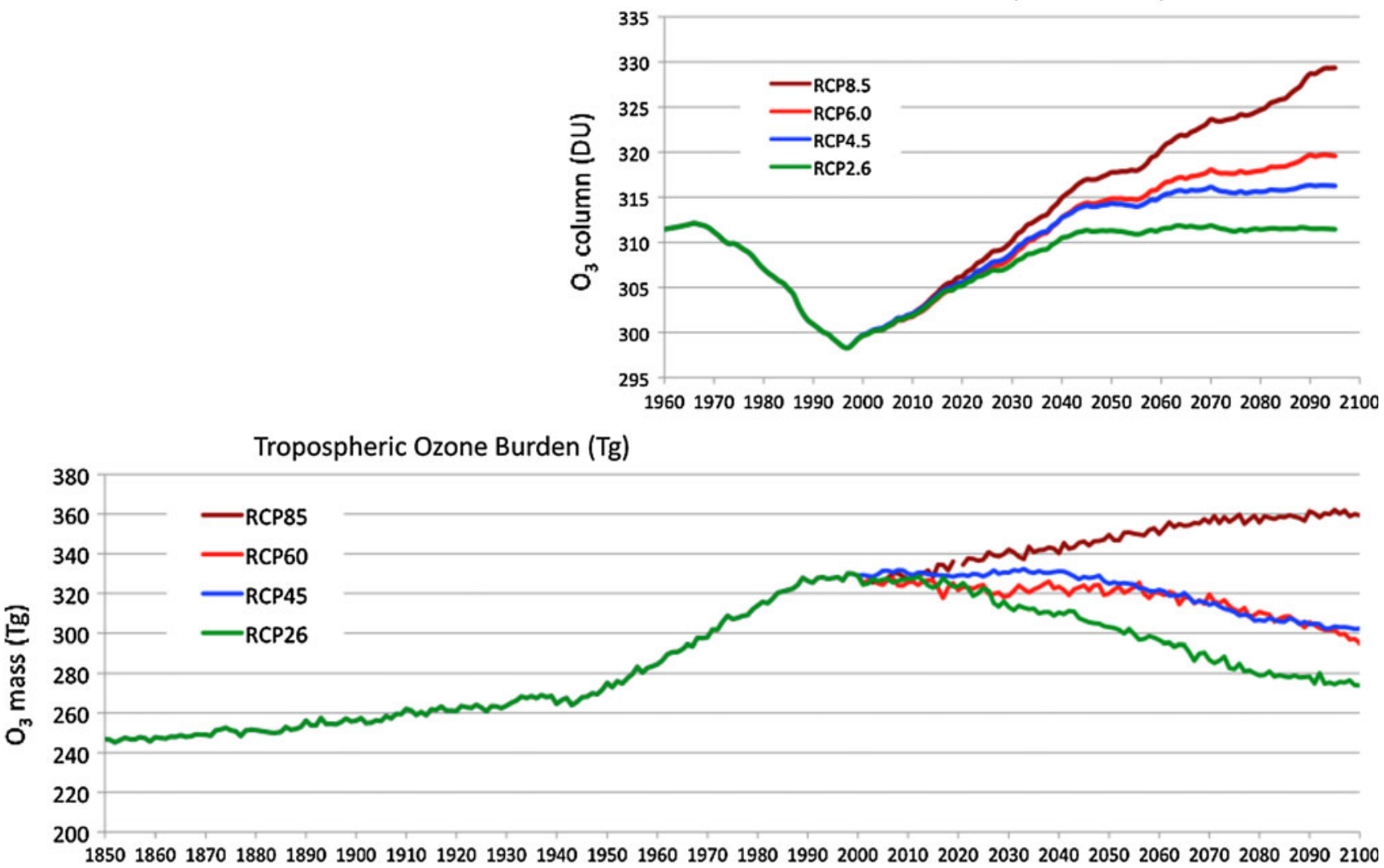

Surface Ozone (global average in ppb)

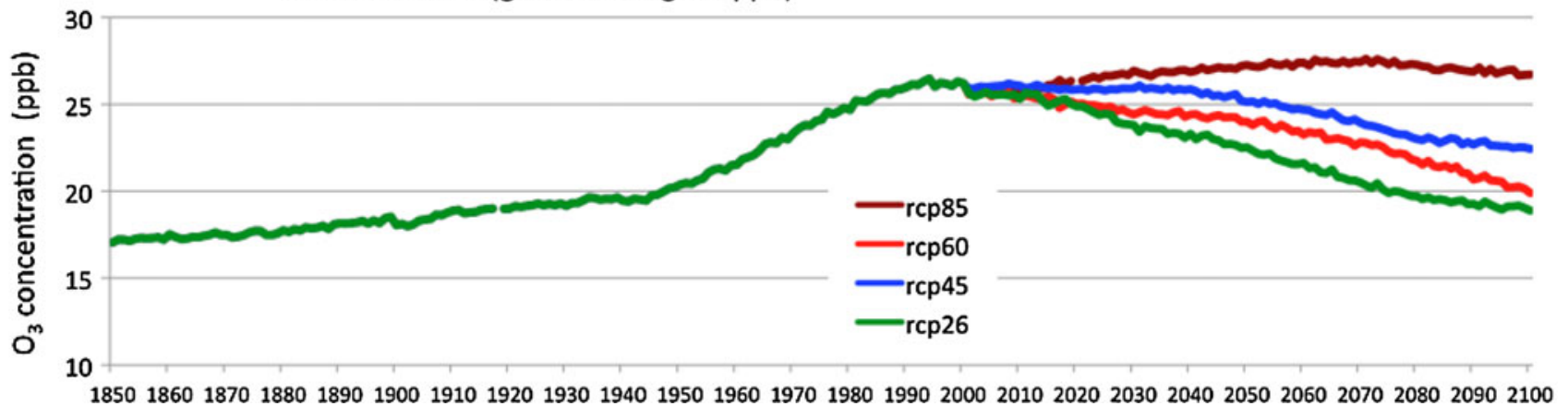

Fig. 6 Evolution of ozone between 1850 and 2100 shown as total ozone in the temporally averaged climatology (in DU, upper panel), tropospheric ozone burden in the INCA simulation (in Tg, middle panel) and surface ozone in the INCA simulation (in ppbv, lower panel)

the precursor emissions from this scenario decrease strongly after 2030, with the exception of methane. The global tropospheric ozone increase is mainly due to $\mathrm{CH}_{4}$ and regional precursor emission increases over India and some parts of Africa (Central and South Africa as well as Gulf of Guinea). Figure 8 shows the map of surface ozone differences for each RCP scenario in the 2050s compared to the present-day. For RCP8.5 (upper left), a significant decrease of surface ozone in North America is simulated together with a strong increase over India $(>8 \mathrm{ppbv}$ locally). African surface ozone also exhibits a large increase (4-8 ppbv) over a large part of the continent and particularly over the tropics. The responses of Europe and South America are spatially contrasted and range in 2050 between $[0 ; 4.5] \mathrm{ppbv}$ and $[-1.5 ; 3.5]$ ppbv respectively. The three other scenarios (RCP6.0, 4.5 and 2.6) lead to an ozone decrease either following a stabilization period (e.g. between 2010 and 2040 for RCP4.5) or as early as 2010. Looking at the global scale (Fig. 6), the RCP4.5 and RCP6.0 trajectories are relatively close. However the ozone evolution corresponds to relatively different regional patterns. As shown in Fig. 8, not only the amplitude of regional changes is different (e.g. a stronger decrease over USA in RCP4.5 compared with RCP6.0) but also the socio- 


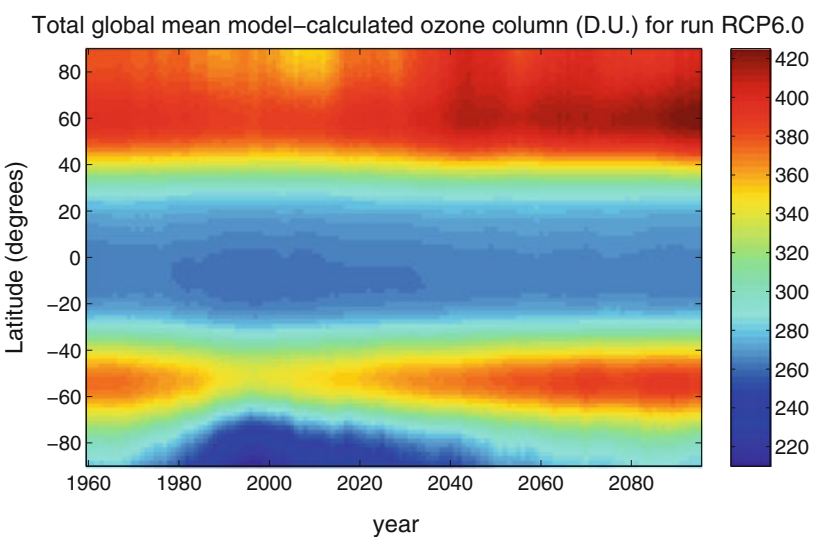

Fig. 7 Evolution of the latitudinal mean total ozone (in Dobson Unit) during the 1960-2000 historical period and during the 2000-2100 according to the RCP6.0 scenario

economical hypotheses underlying the emission projection as is the case for Asia. The RCP6.0 leads to an increase of surface ozone over China and Indonesia whereas RCP4.5 results in a significant decrease over China/Indonesia but in a strong increase over India. In 2100, while RCP6.0 global surface ozone decrease is greater than the one of RCP4.5, the global ozone burden remains close to each other.

The RCP2.6 shows a strong and almost constant ozone decrease of about 0.07 ppbv/year. The surface ozone decreases in the northern hemisphere but increases in some tropical regions. However in this scenario it is surprising to see that global surface ozone is lower than the 1950s level from 2070 until the end of the century.

In 2030, the surface ozone trajectories of the four RCPs lie in the range of previous projections performed with LMDz-INCA during the PHOTOCOMP project (Szopa et al. 2006). The RCP projections are comprised between the scenarios corresponding to the storyboards 'Maximum Feasible Reduction' (matching the RCP2.6) and 'Current Legislation' (matching the RCP8.5) (Dentener et al. 2005).

\subsection{Aerosols}

Figure 9 shows the evolution of the global aerosol optical depth at $550 \mathrm{~nm}$ between 1850 and 2100 as simulated by

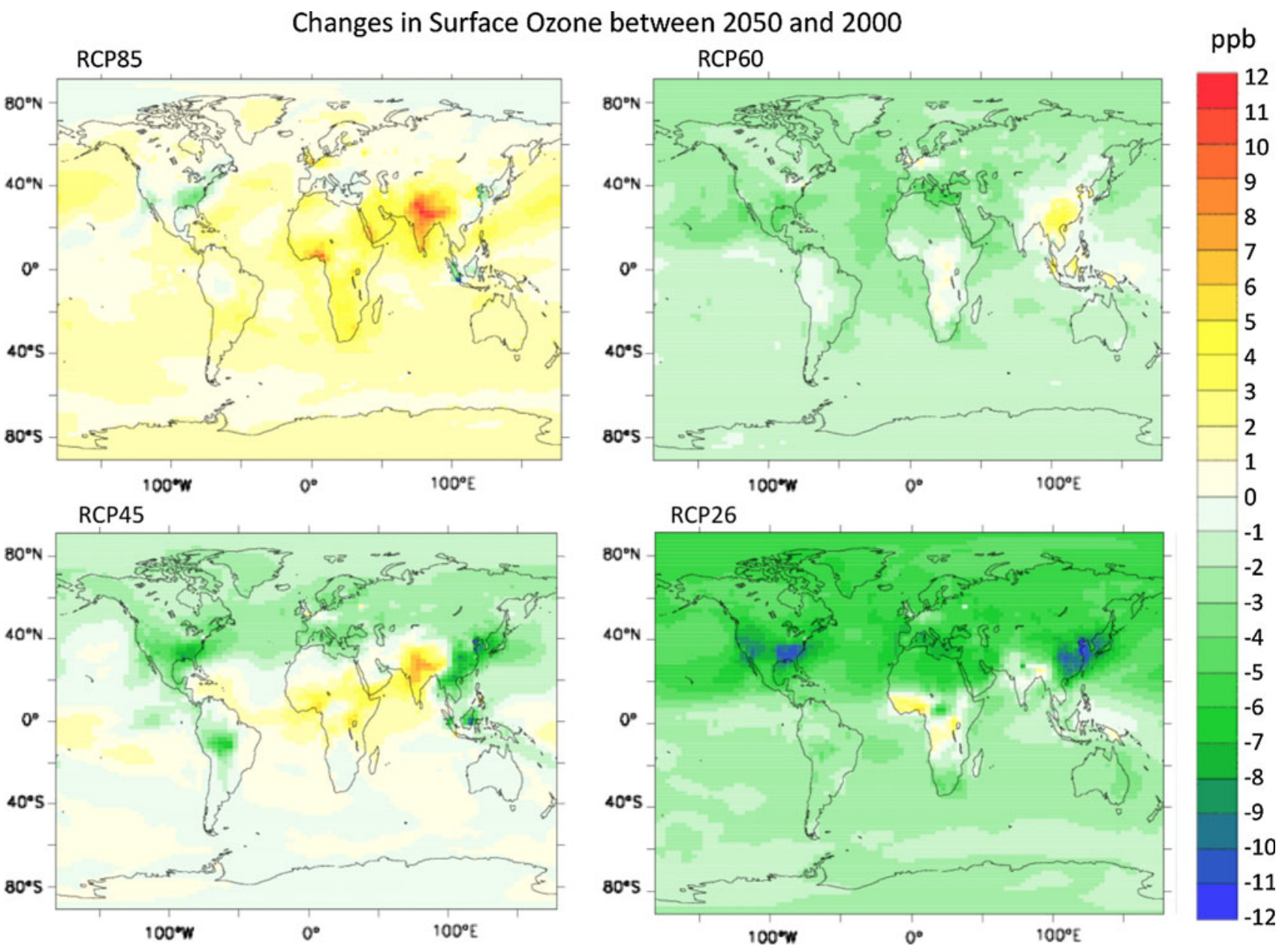

Fig. 8 Distribution of surface ozone changes in 2050 compared with 2000 for the 4 RCP scenarios (using 10 year means) 
Fig. 9 Evolution of the global aerosol optical depth at $550 \mathrm{~nm}$ between 1850 and 2100 shown by types of aerosols simulated by the LMDz-OR-INCA model and then averaged using a 11 -year running mean. The evolution after 2000 is simulated according to the 4 RCP scenarios

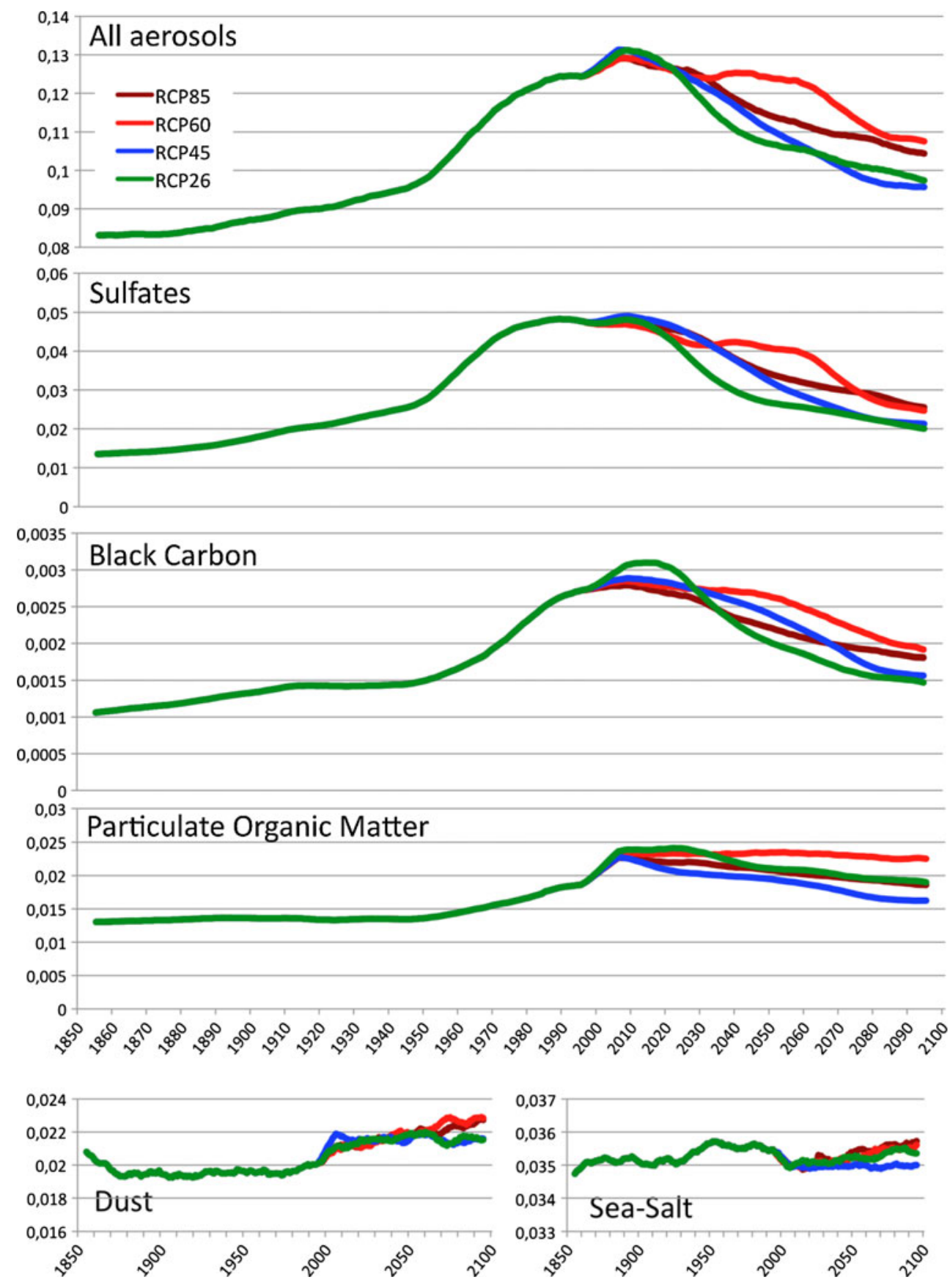

LMDz-OR-INCA and averaged using a 11-year running mean. At the global scale, the historical period can be divided into three sub-periods: $1850-1950,1950-1990$ and post 1990 periods. The $1850-1950$ period shows a slight, but constant increase in the aerosol content, mainly due to the increase of sulfate and black carbon over North-Eastern America and Europe (with regional changes exceeding a factor of 10 for sulfates). The 1950-1990 period exhibiting a strong increase of the global aerosol content slightly smoothed over, from the 1980s, by the slowdown in sulfate increase. In the last decade of the twentieth century, the global content of aerosol is almost stable due to compensation between the strong decrease of aerosols over Europe and North of America (especially sulfates) and an increase of all types of aerosols over Southern and Eastern Asia. In the twenty-first century simulations, an increase with a growth rate equivalent to that of the 1950-1990 period is simulated for the first decade of the twenty-first century. It is explained by a strong increase of particulate organic matter over central Africa and sulfates over Asia for the four RCPs. After 2010, the projections show different evolutions both in term of types of aerosols and regional 
features. The common characteristic is the general decline in the global aerosol content (and for all anthropogenic components) between 2010 and 2100. However, two exceptions to this general decline occur. First, a burst of sulfates over Asia between 2030 and 2080 in the RCP6.0 scenario leads to a subsequent slowdown of the global total aerosol decrease. The second notable feature is a delay (compared to other RCP) of the inversion of the growth rate in the RCP2.6 scenario due to a large increase of black carbon content over Asia which precedes a faster decline of aerosol content finally reaching in 2100 a level close to the one simulated before 1950 (also for the RCP4.5). The final content in 2100 for RCP6.0 and 8.5 is equivalent to the 1960s level. Whereas wind fields used to generate dust and sea-salt uplifts remain the same throughout the entire simulations, as described above, the dust and sea-salt contents evolve with time. The large increase of dust AOD $(>10 \%)$ is correlated in these simulations with a longer lifetime, due to a changed pattern of wet deposition in future climate. Indeed, even if the global value of precipitation increases in a warmer climate, the precipitation changes vary in amplitude and sign depending on the location (Dufresne et al. this issue). Regarding dust, the wet deposition is strongly weakened around $40^{\circ} \mathrm{N}$ due, in particular, to the precipitation decrease over a large area around the Black Sea.

In the previous CMIP exercise, the IPSL-CM4 considered only sulfate evolutions computed by Boucher and Pham (2002) for historical period and Pham et al. (2005) for future projections based on the SRES scenarios. For the historical period, the values and distribution of emissions provided by Lamarque et al. (2010) are similar to those of Boucher and Pham (2002). The slight decline of global emissions between 1980 and 1990 is similar. The Lamarque et al. (2010) dataset extends longer (up to the year 2000), with a strong emission decline (>16\%) over the last decade. Some very large differences can be pointed out between the RCP trajectories and the SRES scenarios for future projections. In the SRES trajectories, four of the six scenarios lead to a peak in sulfate content followed by a rapid decrease, which slowed down around 2080. The two other scenarios exhibited an almost constant value of sulfate load throughout the whole twentyfirst century or a constant decrease leading, at the end of the century, to a value equivalent to $37 \%$ of the 2000 global content. This last SRES scenario (A1T) is intermediate between the RCP2.6 and RCP4.5 projections regarding sulfate evolution. However, this scenario was skewed towards non-fossil energy source. Besides this drastic scenario, the cleanest realistic scenarios are the B1 family relying on the introduction of clean and resource efficient technologies together with reductions in material intensity. Such clean scenarios exhibit higher sulfate content than the RCP simulations, either temporarily or over the whole century.

\section{Radiative Forcings due to chemical climate forcing agents}

The impact of the evolution in the chemical atmospheric composition on climate is presented here in terms of radiative forcing (RF), which represents the radiative imbalance in the climate system at the top of atmosphere caused by the addition of a greenhouse gas (or other change), as stated by the 1st IPCC report (IPCC 1990). Figure 10 shows the present day radiative forcing for each anthropogenic chemical forcing agent, both long- and short-lived, as estimated by the IPSL-CM5a-LR Earth System Model. Some of them are computed individually and were archived during the ESM simulations, some others were computed afterwards with the GCM radiation scheme to isolate the role of each compound and, as a consequence, with a slightly different protocol. The total aerosol direct and indirect effects were diagnosed on-line and archived during the IPSL-CM5a-LR simulations. For separate components of the aerosols, radiative forcing diagnostics are calculated as total instantaneous forcing referenced to preindustrial aerosols. The present-day climate is used for these computations whatever the period investigated. For ozone and LL-GHG, however, they are referenced to the 1850s GHG content. The RF of gaseous species are computed considering a 1850s climatological climate and after thermal adjustment of the stratosphere. As described in the IPCC (2001) report, the radiative forcing is defined as the imbalance of the net radiation at the tropopause since the stratosphere adjusts in a few months after a perturbation whereas the troposphere adjusts far more slowly due to the thermal inertia of the oceans. In order to compute radiative forcing with a thermal adjustment of the stratosphere, the radiative code iterates until the RF at the top of the stratosphere converges with the RF at the tropopause. Compared to the evaluation done in the 4th IPCC (2007), which can be considered as a useful reference point, the respective impacts of the climate forcing agents are correctly ranked. However, the $\mathrm{CO}_{2}$ and $\mathrm{CH}_{4} \mathrm{RF}$ are respectively under- and overestimated (by at least 7 and $21 \%$ ). The discrepancies between the $\mathrm{CO}_{2} \mathrm{RF}$ computed in this work and the IPCC estimation can be partly explained by the $10 \mathrm{ppm}$ differences between the 1850 and 1750 levels which are used respectively as references. However, for both carbon dioxide and methane $\mathrm{RF}$, the bias is mainly due to a non up-to-date absorption spectrum in the radiative code. For other species, in particular ozone and aerosols, the mean RF computed by $\mathrm{LMDz}$ lies in the $90 \%$ confidence interval of the IPCC 


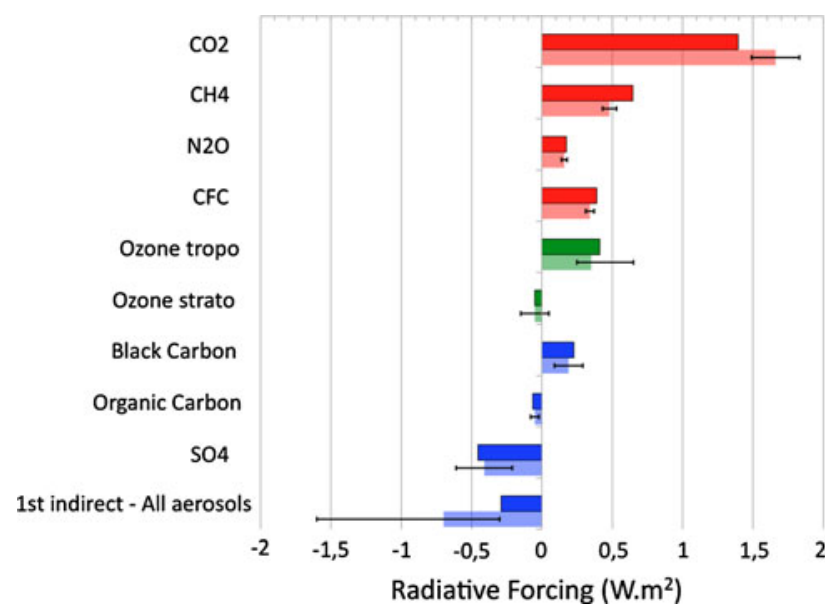

Fig. 10 Global averaged radiative forcing (RF) estimates in 2000s in the IPSL-CM5 model for anthropogenic carbon dioxide $\left(\mathrm{CO}_{2}\right)$, methane $\left(\mathrm{CH}_{4}\right)$, nitrous oxide $\left(\mathrm{N}_{2} \mathrm{O}\right)$, chlorofluorocarbons $(\mathrm{CFCs})$, and 2000 for tropospheric and stratospheric ozone and aerosols (black and organic carbon, sulfates). The pastel bars indicate the RF values reported in the IPCC 2007 with their $90 \%$ confidence interval

report. The first indirect forcing of aerosol (cloud albedo effect) is estimated at $-0.29 \mathrm{~W} \mathrm{~m}^{-2}$, which is almost equal to the lowest range of estimation.

During the last decade, the quantification of the first indirect effect evolved significantly in the successive works based on the IPSL modeling infrastructure reflecting the large uncertainties in the mechanisms involved in the quantification of this effect. Hence, Boucher and Pham (2002), considering only the sulfate aerosol, computed an indirect effect of $-1 \mathrm{~W} \mathrm{~m}^{-2}$ between 1850 and 1990 using the LMDz atmospheric model. Then, efforts were done to use satellite data to adjust the parameters of the empirical relationship between the cloud droplet number concentrations and the aerosol mass concentration (see Sect. 2.5) in the GCM (Quaas and Boucher 2005; Quaas et al. 2004a, b; Dufresne et al. 2005). These modifications came in addition to cloud cover changes due to the coupling of the atmospheric model with the ORCHIDEE land surface model for the hydrological cycle. Still using the Boucher and Pham (2002) sulfate content, the resulting indirect forcing was assessed to be $-0.2 \mathrm{~W} \mathrm{~m}^{-2}$ between 1850 and 1995 (Dufresne et al. 2005). More recently, Déandreis et al. (2011) found a $-0.39 \mathrm{~W} \mathrm{~m}^{-2}$ indirect forcing for sulfate using the IPSL-ESM reading aerosol fields computed offline (same configuration as the one retained in IPSL-CM5) between natural and present-day aerosol distributions (as simulated for AeroCom and representing the year 2000). The reason of the difference with the value found in this work $(-0.29)$ is twofold. First, contrary to IPSL-CM4, the mass of all soluble part of aerosols simulated by INCA (dust, sea-salt, particulate organic matter and black carbon) is taken into account, which can lead to an increase of the number of cloud condensation nuclei, where the sulfate concentrations are low. It results in an increase of a few tens of milliwatts per square meters of the global indirect effect (Déandreis, personal communication) since the relation between CDNC and aerosol concentration is highly non-linear and reaches a plateau beyond a $50 \mu \mathrm{g} \mathrm{m}^{-3}$ aerosol content (Déandreis et al. 2011, Fig. 1). Secondly, the IPSL-CM5aLR configuration leads to a significantly colder climate than the IPSL-CM4 configuration $(-0.7 \mathrm{~K}$ on the global mean temperature), which can lead to an increase of low level cloud cover (Brient and Bony 2012, this issue). Such increased cloud cover, if matching the aerosol distribution, is favourable to an increase of the indirect aerosol effect (Dufresne et al. 2005). The indirect effect estimation will

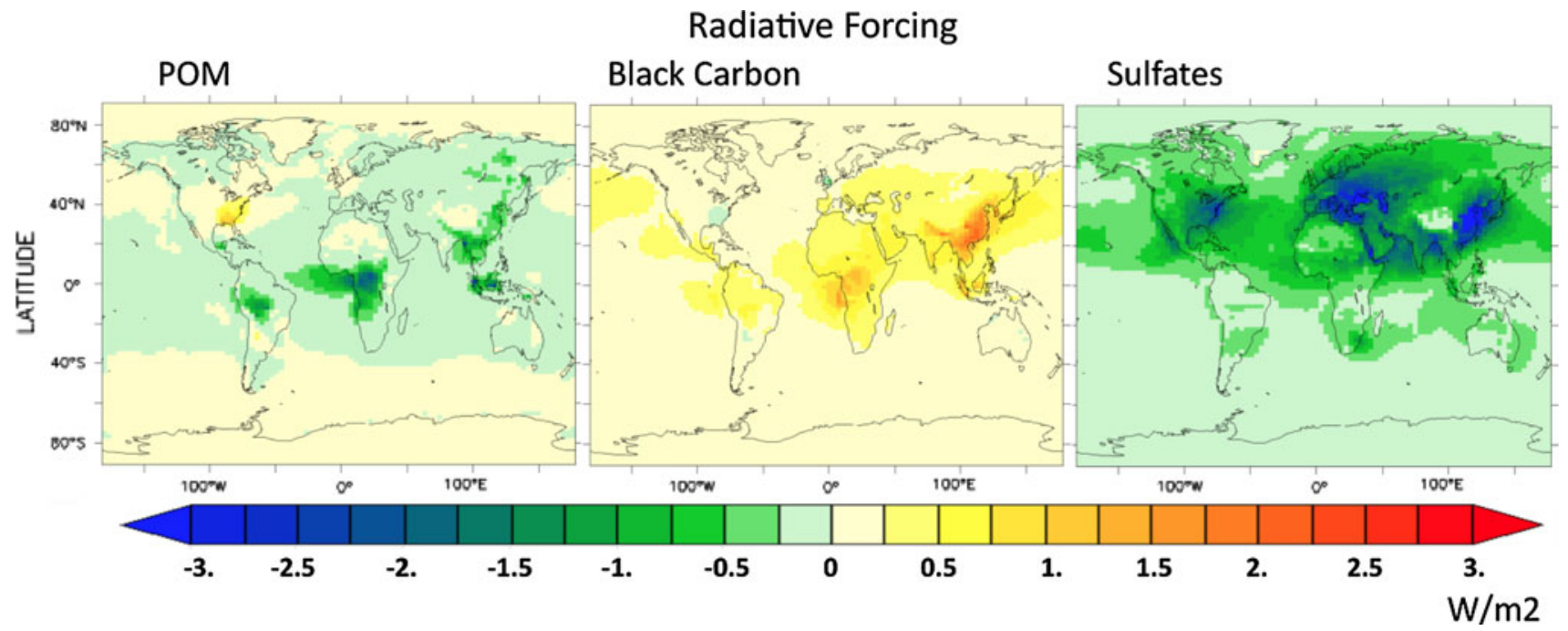

Fig. 11 Top of atmosphere shortwave radiative forcing due to three anthropogenic aerosol components in 2000 


\section{TOA Radiative Forcing of aerosols}

(all components)

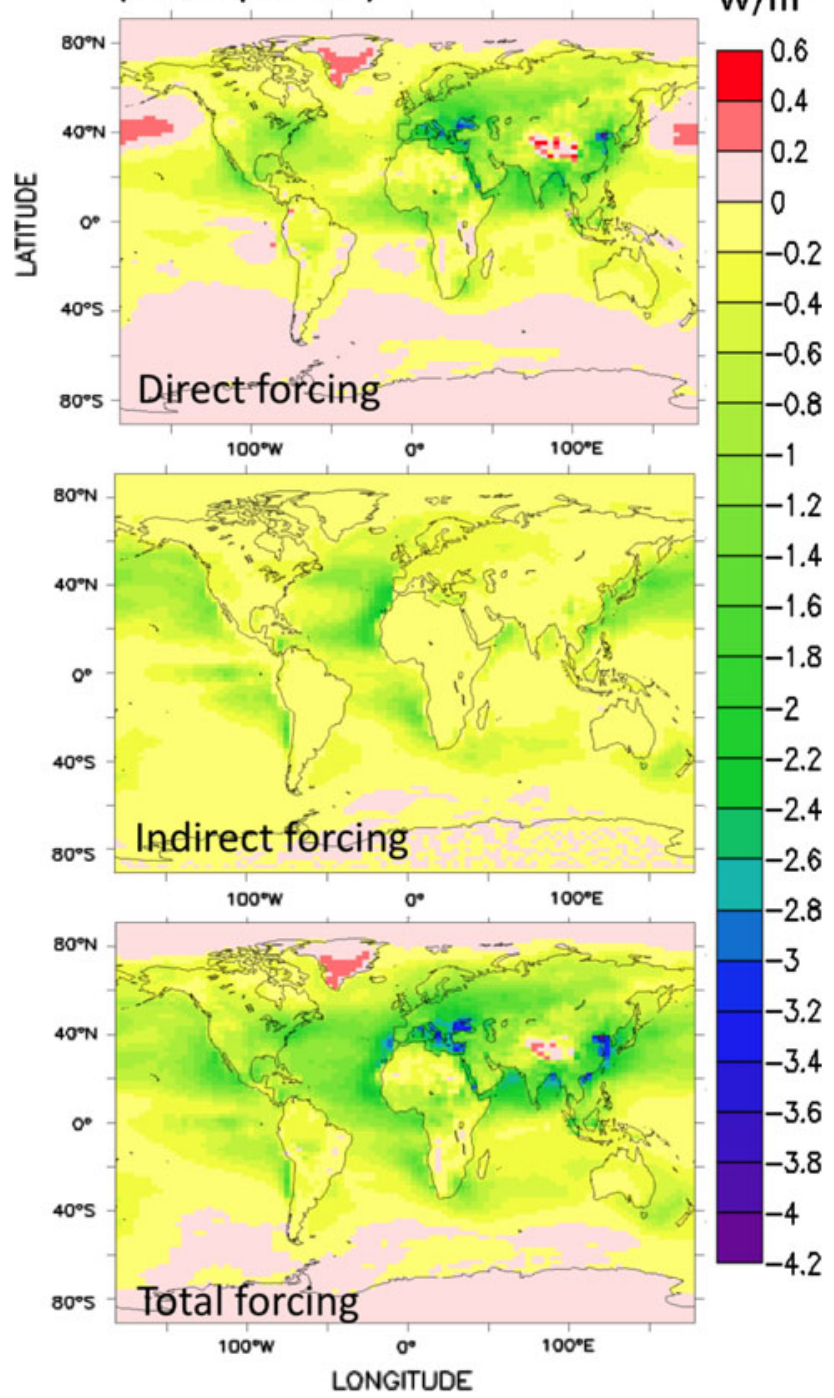

Fig. 12 Shortwave direct and indirect radiative forcing due to all type of aerosols in 2000 computed by the IPSL-CM5 ESM model

probably increase in the coming version of the IPSL infrastructure IPSL-CM5b, in which low-mid level cloud coverage is improved (and increased) thanks to more sophisticated physical parameterizations, in particular the convective boundary layer representation (Hourdin et al., this issue).

The geographical pattern of the RF for the year 2000 is presented for different aerosol components (Fig. 11), for total aerosols (Fig. 12) and tropospheric ozone (Fig. 13). The regional feature of the influence of aerosols is well represented with regional maximum cooling due to sulfates exceeding $-3 \mathrm{~W} \mathrm{~m}^{-2}$ over Europe, East Coast of USA, Asia and the Arabian sea and a warming reaching up to $2 \mathrm{~W} \mathrm{~m}^{-2}$ due to black carbon over Asia and over the Gulf of Guinea. As a consequence, the total direct aerosol forcing is maximal over central Europe, Arabian Sea, Bay of Bengal, Red Sea and Yellow Sea where the cooling exceeds $-2 \mathrm{~W} \mathrm{~m}^{-2}$. Figure 14 (lower panels) illustrates the contrast in the evolution in term of aerosol RF over Asia and Europe. The indirect cooling effect occurs mostly over ocean associated with large areas having the highest values along the North Western African coast in the North Atlantic and off the Japan coast in North Pacific.

For tropospheric ozone, the forcing is almost exclusively positive and shows the highest values between $15^{\circ} \mathrm{N}$ and $40^{\circ} \mathrm{N}$, with maximum values $\left(>0.7 \mathrm{~W} \mathrm{~m}^{-2}\right)$ over a large area surrounding the North Africa/Arabian Peninsula and India, as already found by previous studies (e.g. Gauss et al. 2006).

Figures 14 and 15 show the evolution of the RF due to ozone and aerosols respectively throughout the twentieth and twenty-first centuries. The radiative forcing of tropospheric ozone evolves similarly to the ozone burden. After a stabilization period around $0.4 \mathrm{~W} \mathrm{~m}^{-2}$ between 1990 and 2010, RF increases in the RCP8.5 scenario, reaching $0.62 \mathrm{~W} \mathrm{~m}^{-2}$ in 2100 . The RF in RCP6.0 and RCP4.5 starts to decrease after 2060 , reaching $0.3 \mathrm{~W} \mathrm{~m}^{-2}$ in 2100 . The RCP2.6 leads to a constant decrease of the tropospheric ozone RF after 2010 leading to $0.16 \mathrm{~W} \mathrm{~m}^{-2}$ in 2100 . This positive RF is partly counteracted by the negative RF of stratospheric ozone. For the historical period, the stratospheric ozone RF peaks in the 1990s $\left(-0.15 \mathrm{~W} \mathrm{~m}^{-2}\right)$ before reaching around 2030-2040 a stabilization period with a lower impact $\left(\sim-0.1 \mathrm{~W} \mathrm{~m}^{-2}\right)$. The stratospheric ozone RF projections from the different scenarios diverge after 2040. In RCP8.5 and, to a lesser extent, in RCP6.0, the stratospheric ozone RF increases (decreases if the sign is taken into account) again throughout the second part of the century to reach values well below the maximum RF of the 1990s. For example, it reaches $-0.25 \mathrm{~W} \mathrm{~m}^{-2}$ in 2090 in the RCP8.5 scenario. In contrast, the stratospheric ozone $\mathrm{RF}$ remains constant in RCP4.5 and even decreases in the RCP2.6. The differences are due to the differences in the evolution of ozone in the tropical lower stratosphere. Indeed, as discussed by Forster (1999), the global stratospheric ozone RF is very sensitive to the ozone trend assumed in the tropical lower stratosphere (Hansen et al., 2005). For example, he found that including in RF calculations not statistically significant ozone trends in the tropical lower stratosphere would modify the results by several fold. In all the scenarios, tropical lower stratospheric ozone decreases throughout the twenty-first century. The main mechanism driving this evolution is the GHG-driven increase in tropical upwelling during the twenty-first century, which is a robust feature in the CCM simulations (WMO 2011). The increase in tropical upwelling is the strongest in RCP8.5, the scenario with the maximum increase in GHG. As a result, the tropical lower 
Fig. 13 Top of atmosphere radiative forcing due to tropospheric ozone in 2000

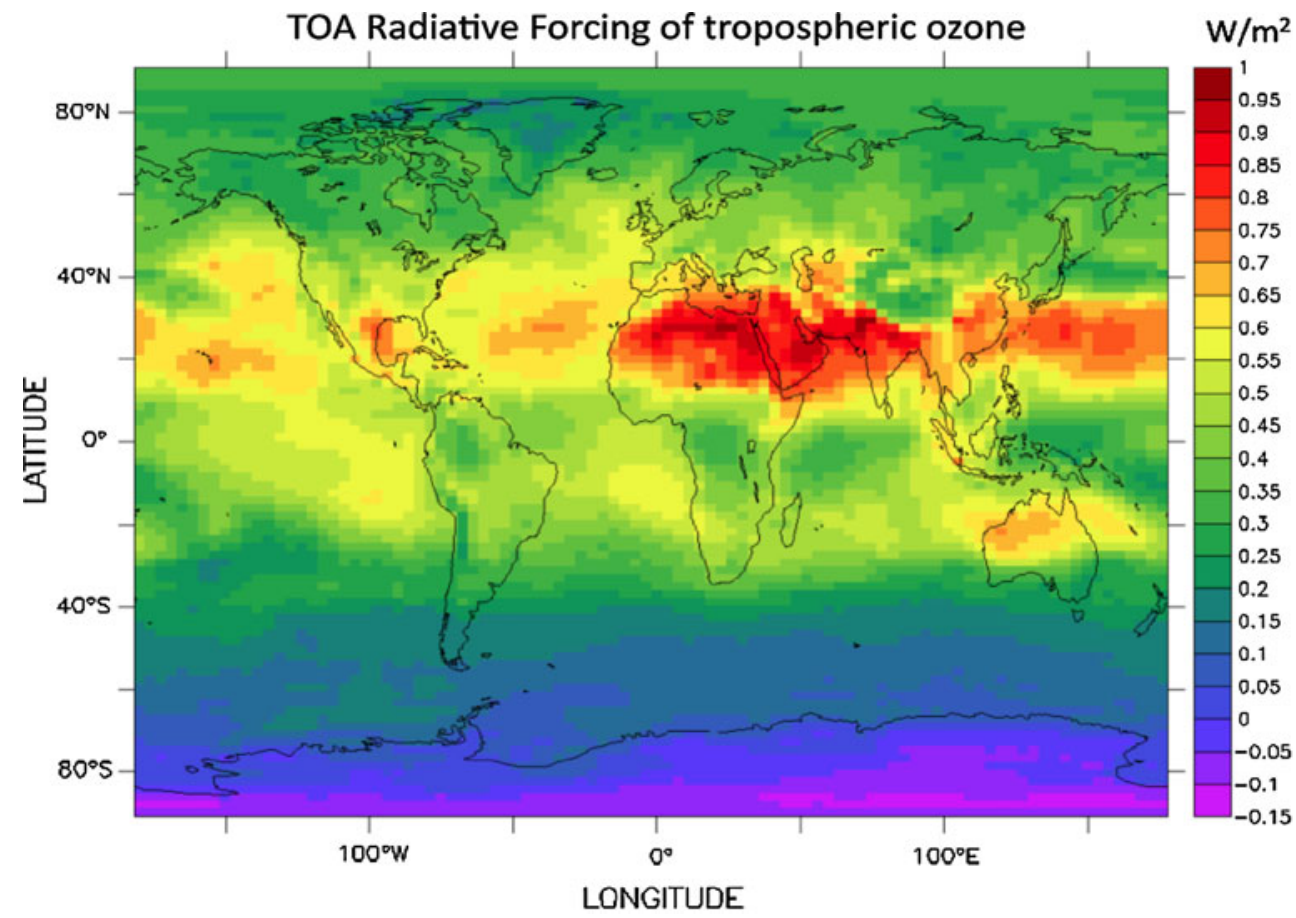

stratospheric ozone decrease is also the most pronounced in RCP8.5 and hence the negative RF carries on decreasing. At the other end of the scenario spectrum, in RCP4.0 and RCP2.6, the increases in the tropical upwelling and in the associated ozone depletion are much more limited throughout the twenty-first century, leading to much smaller changes in the stratospheric ozone RF (WMO 2011). Note that the ozone RF trajectories presented here match well those presented in Cionni et al. (2011) for the same scenario even if the absolute values of RF are slightly higher, but still within the AR4 interval.

Figure 16 shows the response of direct radiative forcing caused by aerosols as a function of the total AOD. Some subsets of the simulations show linear relationships between AOD and RF but the slope can differ strongly between the subsets. On the contrary, for some part of the simulations, no evident link between RF and AOD can be found. In fact, since the geographic pattern of the aerosol radiative effect is heterogeneous, the sensitivities of the total aerosol direct RF to the trends in aerosol loads vary depending on the region and type of aerosols dominating the aerosol changes. Between 1880 and 1980, the increase in aerosol is dominated by the increase in sulfate aerosol and consequently, the direct RF is continuously decreasing reaching $-0.34 \mathrm{~W} \mathrm{~m}^{-2}$ in 1980 . Then, from 1980 to 2000 , the increasing fraction of absorbing aerosols (even if the global content of total aerosol remains almost constant) tends to attenuate the general cooling effect of aerosol, which stabilizes during the first years of the twenty-first century around $-0.3 \mathrm{~W} \mathrm{~m}^{-2}$. That is not the case for indirect forcing, which stabilizes as soon as 1980 (around $-0.28 \mathrm{~W} \mathrm{~m}^{-2}$ ) and seems not affected by the nature change of aerosol. Between 1995 and 2006 there is no clear relationship between RF and loads. After 2006, RCP8.5, 4.5 and 6.0 have decreasing total aerosol trajectories, leading to a reduction of the direct global cooling of aerosol. The absolute value of RF decreases linearly with loads but with different slope pointing out the different underlying hypothesis used for each scenario. Figure 17 presents the spatial distribution of the direct radiative forcing of aerosols in 2050 and 2100 for the four RCP scenarios. It clearly confirms how different the regional evolution can be among the scenario as well as the regional intensity of the forcing especially over Asia. Hence, the RCP6.0 scenario induces a strong cooling effect over Asia (with values exceeding $-5 \mathrm{~W} \mathrm{~m}^{-2}$ over East China) in the middle of the twenty-first century. Even if the RCP6.0 trajectory is very different over Asia, it does not perturb the continuous attenuation of the indirect effect at the global scale, but it leads to a significant peak of the global cooling effect resulting from direct forcing. In 2100, the effects are weaker than $-2 \mathrm{~W} \mathrm{~m}^{-2}$ everywhere and for all scenarios, which is less than the present effect of sulfates alone.

Figure 18 presents the evolution of the RF over the 1850-2100 period considering the RCP8.5 projection for all the atmospheric climate forcing agents considered in the IPSL-CM5 model. According to the RCP projections, the cooling effect of aerosol becomes small in the twenty-first 
(a) Total Direct Aerosol Radiative Forcing

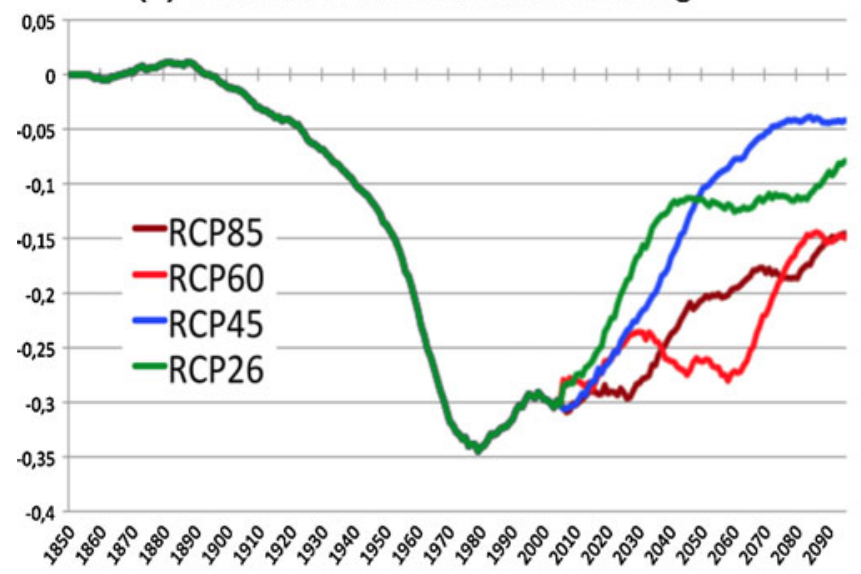

(c) Total Direct Aerosol Radiative Forcing over Asia

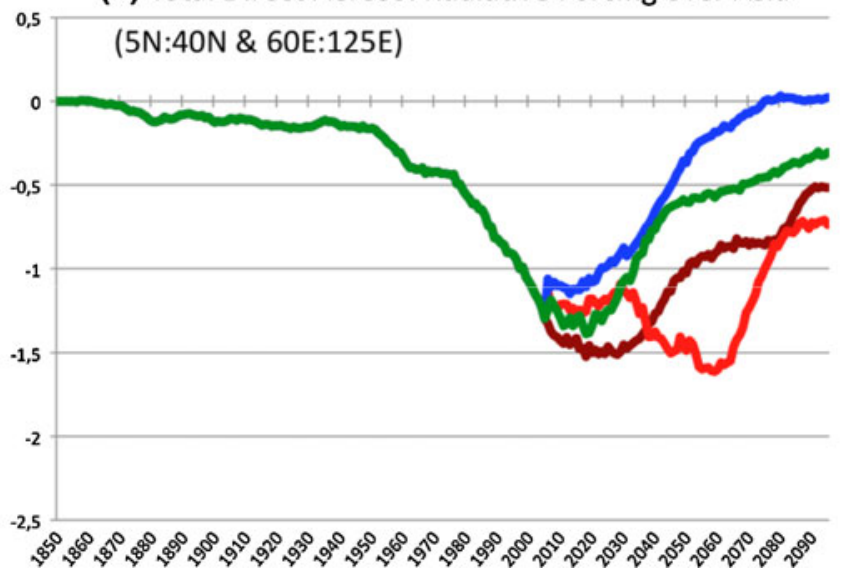

(b) Total Indirect Aerosol Radiative Forcing

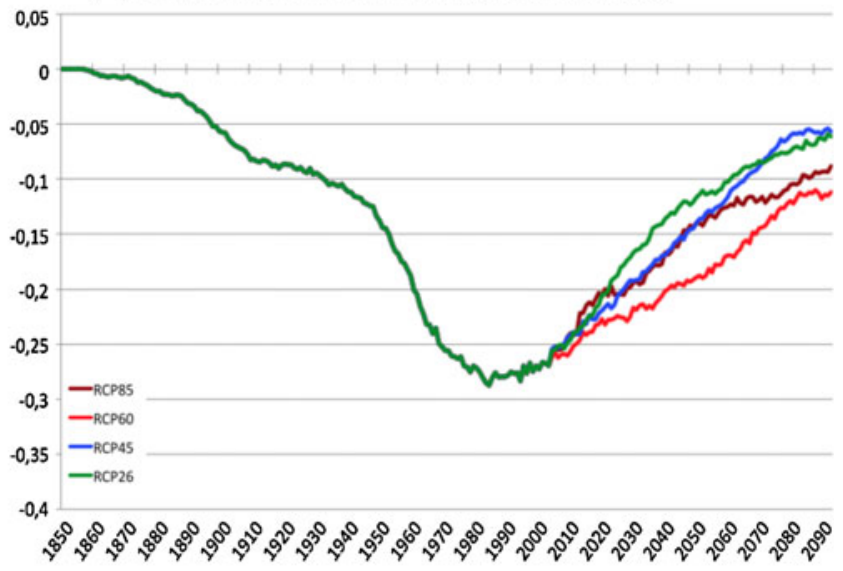

(d) Total Direct Aerosol Radiative Forcing over Europe

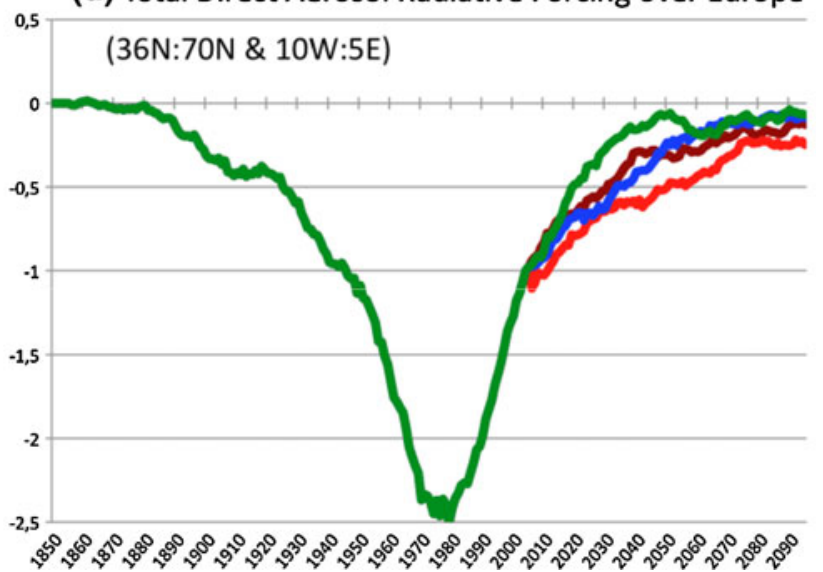

Fig. 14 Evolution of the direct and indirect radiative forcings of aerosol at the global scale and of the direct forcings over Asia and Europe

century compared to the GHG increase. This is true for all RCP scenarios as can be seen in Dufresne et al. (this issue). This was already pointed out by Dufresne et al. (2005) for SRES projections but it is even more striking here because of (1) RCP projections relying on a strong emission decrease for aerosols, (2) black carbon, having a warming effect, which was added to the atmospheric model and (3) indirect effect, weaker than in first estimates within the IPSL modeling infrastructure. The ozone is also now considered in these simulations and plays a warming role during the whole twenty-first century (considering total ozone) according to these scenarios. The amplitude of the total ozone effect is of the same order as that of the cooling effect of aerosol.

Among the perspectives to improve the quantification of chemical compounds on the climate system, the on-line simulations of atmospheric composition are a promising way. Hence, Déandreis et al. (2011), show an impact equivalent of $30 \%$ of the direct radiative forcing solely due to the impact of a high frequency variation of sulfates (compared with monthly mean) on radiative forcing computations. Furthermore, although computationally costly, only on-line chemistry-climate simulations would allow quantification of regional feedbacks such as ozone impact on vegetation or via interplay between carbon and nitrogen biogeochemical cycles both being directly or indirectly linked to $\mathrm{VOC} / \mathrm{NO}_{x} / \mathrm{OH}$ gaseous chemistry, secondary organic aerosols and ammonia/nitrate equilibrium. According to RCP projections, the ammonia emissions increase in all the RCP scenarios during the twentyfirst century with 2100 values corresponding to a $50 \%$ increase of the 2000 emissions. According to the recent Bellouin et al. (2011) study, nitrate aerosols could partially replace sulfate aerosols in the climate system in the remainder twenty-first century. The combining of tropospheric and stratospheric ozone fields is also a weakness of this work and a single model including both chemical schemes would allow more consistency for the upper troposphere-lower stratosphere ozone distribution and stratosphere/troposphere exchanges.

As always in such projection exercise, the emissions can not cover all possible futures. Smith et al. (2011) warn 


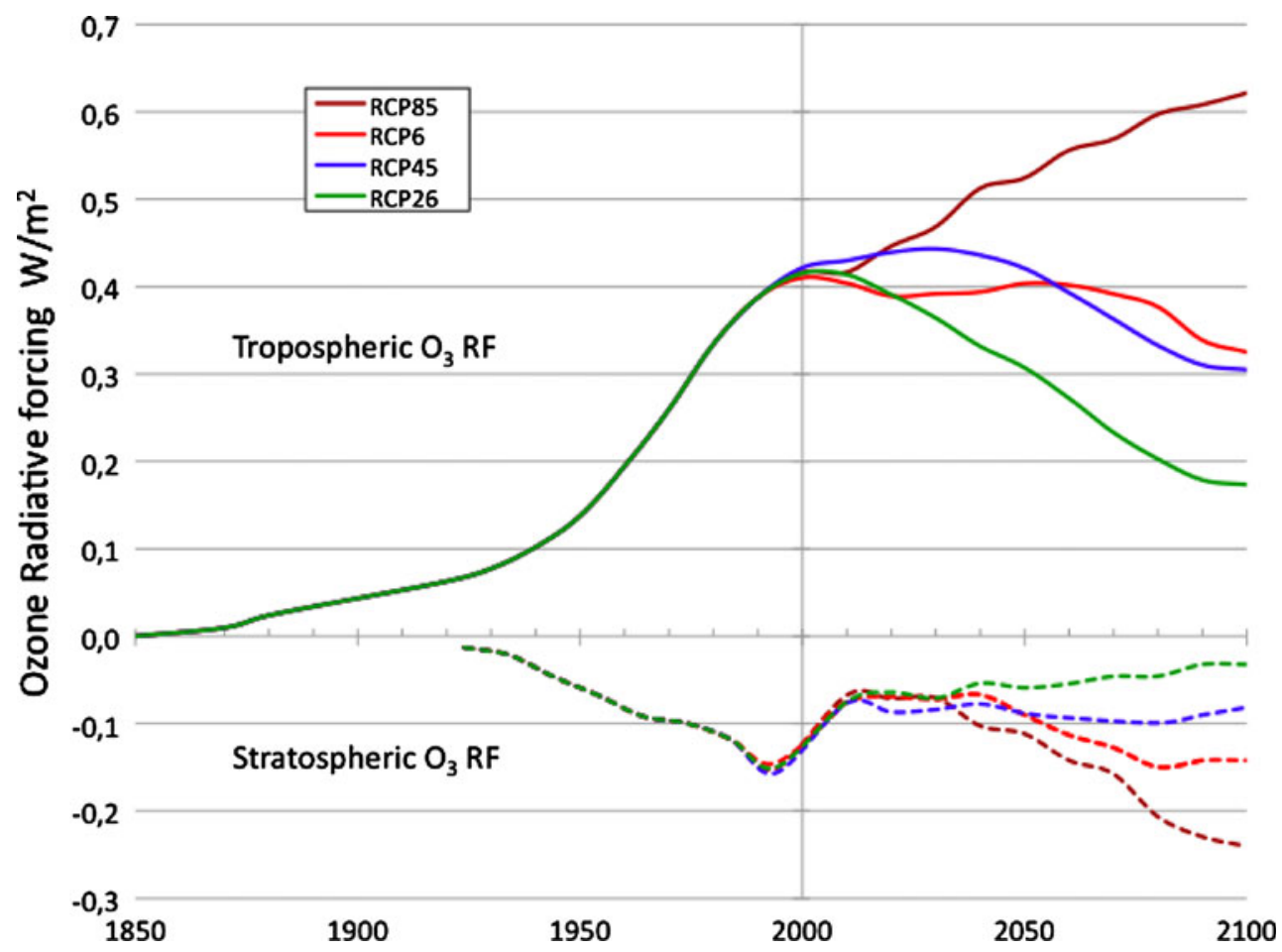

Fig. 15 Evolution of the tropospheric and stratospheric ozone radiative forcings for historical period and RCP scenarios

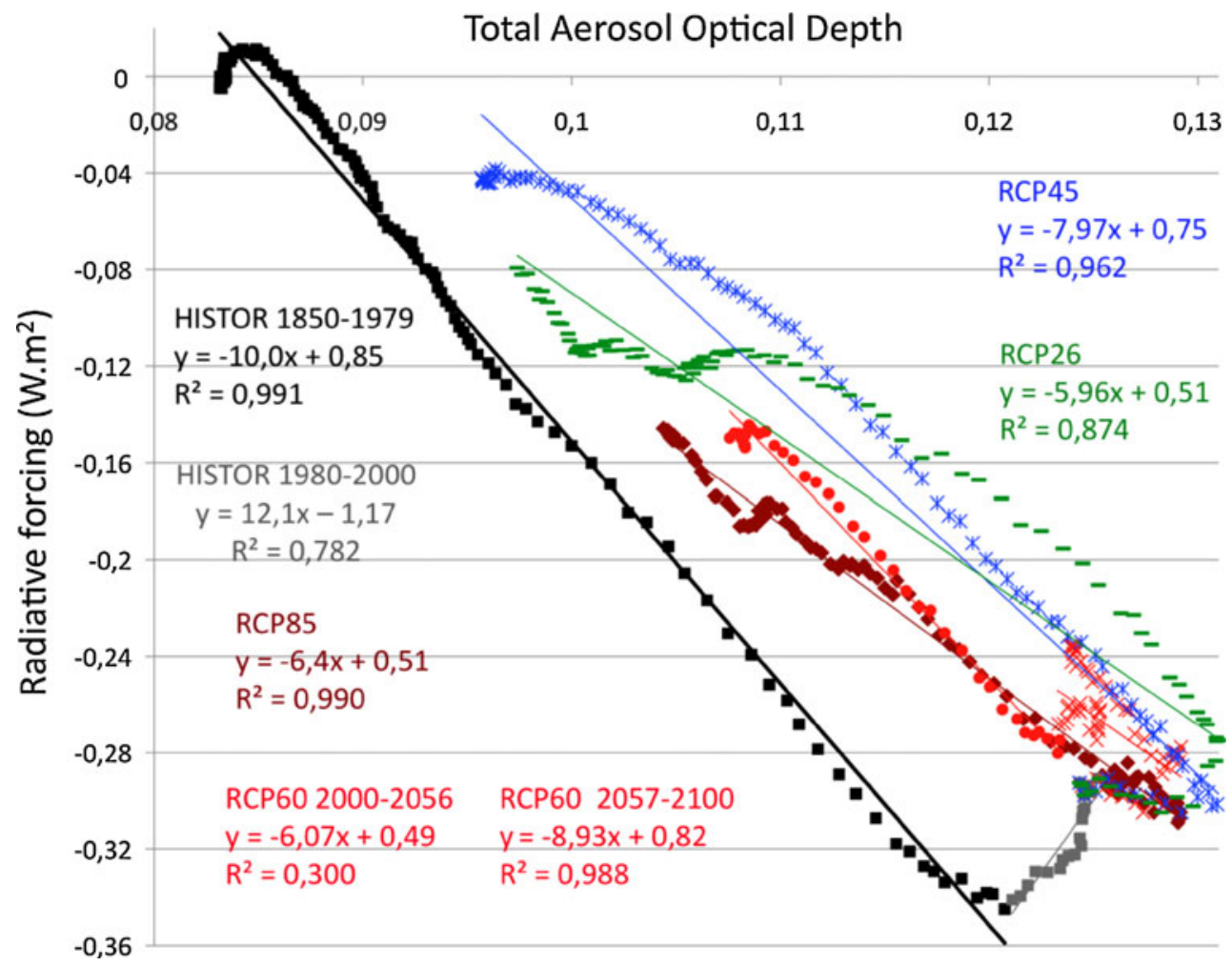

Fig. 16 Direct radiative forcing as a function of total aerosol depth. The linear trend as well as corresponding correlation coefficients are specified 


\section{Total Aerosol Direct Radiative Forcing}
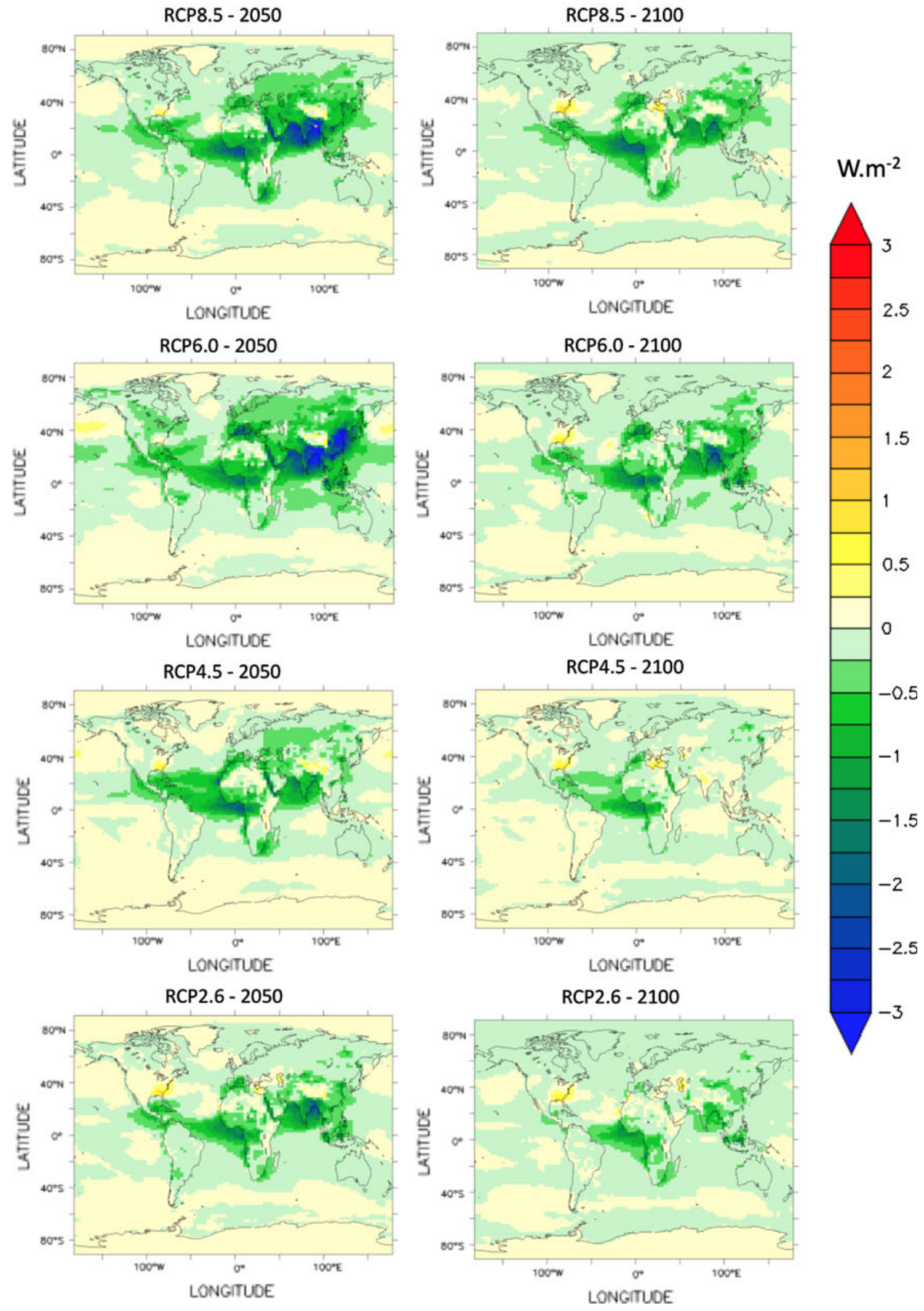

Fig. 17 Shortwave direct and indirect radiative forcings due to all type of aerosols in 2050 and 2100 for the four RCP projections computed by the IPSL-CM5a ESM model 


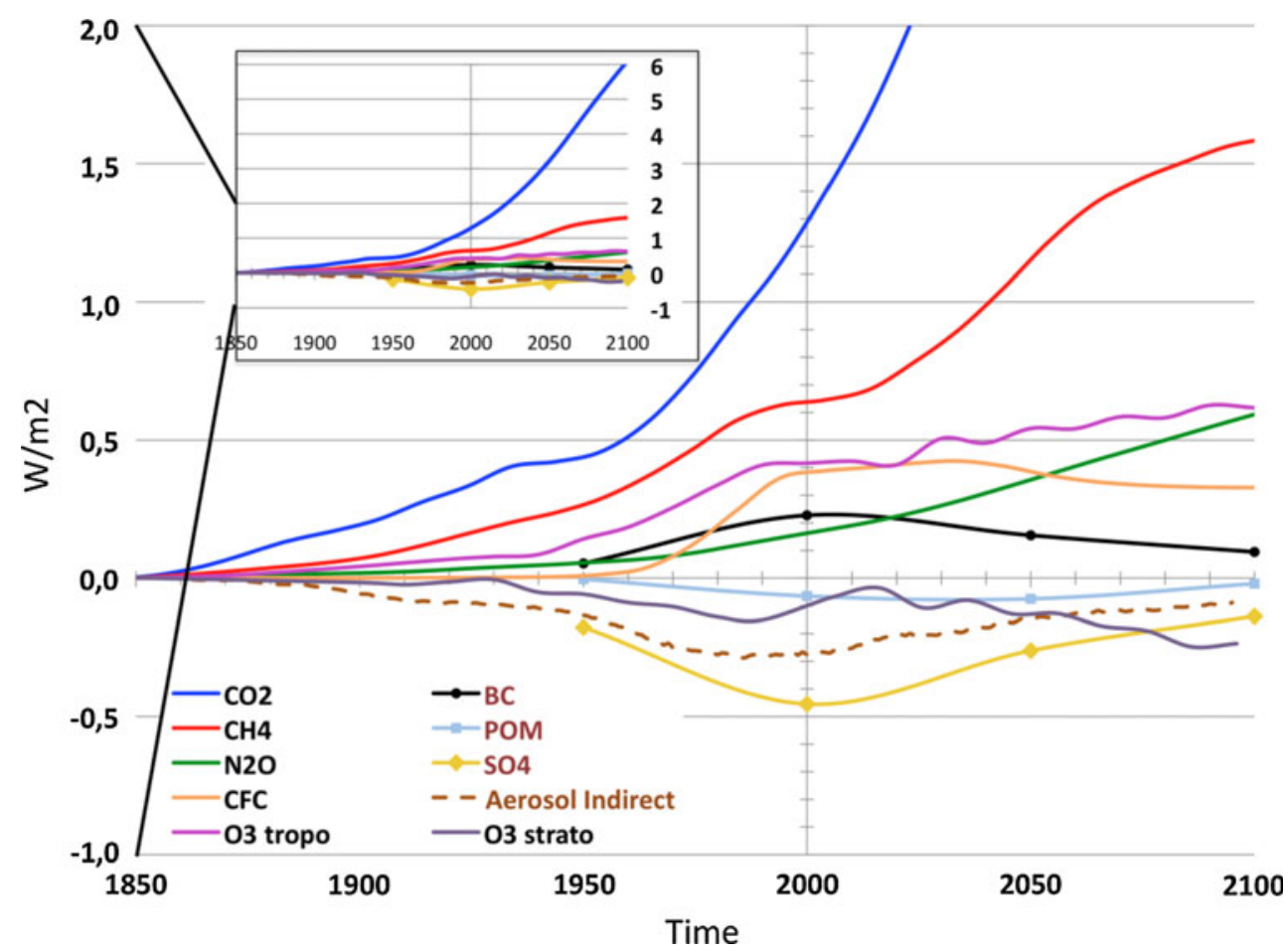

Fig. 18 Evolution of the individual radiative forcings due to chemical climate forcing agents as considered in the IPSL-CM5 historical and RCP85 simulation

against the air pollutant hypothesis underlying the RCP scenarios arguing that they are not necessarily consistent with arbitrary socio-economic pathways. Indeed, these scenarios have in general allowed emission controls to increase with income. Nevertheless, the link between income and pollutant emissions is far more complex with non-linear relationships between emissions and regional concentrations as well as air pollution transport from one region to another. Furthermore, the cost of emission reductions will differ due to geographical specificities, emissions density or population levels (Smith et al. 2011).

\section{Conclusion}

Simulations of the global aerosol (dust, sea-salt, black carbon, particulate organic matter and sulfates) and ozone (tropospheric and stratospheric) distributions between 1850 and 2100 have been performed following a recent historical emission dataset and under the Representative Concentration Pathways (RCP) for the future. In these simulations, only biomass burning and anthropogenic sources are varying from year-to-year. The RCP projections, defined in the IPCC-AR5 framework, allow to investigate four emission trajectories for the 2000-2100 period. Each emission trajectory is compatible with a distinct climate pathway and includes gridded emissions for aerosol and ozone precursors in decadal increment. These simulations were subsequently used by the two French Earth System Models (ESMs) to account for the spatial and temporal evolution of both radiatively and chemically active compounds, when simulating the climate evolution. This paper presents the methodology used to prepare such climatologies for ESMs. Main characteristics and trends shown by the climatologies are discussed for both ozone and aerosols.

The model-calculated present-day distribution of tropospheric ozone is qualitatively compared with two spaceborne thermal infrared spectrometers. Overall, the zonal distribution appears to be correctly reproduced in the model-calculated climatology including the summer increase of ozone in the lower levels of Northern midlatitudes. The discrepancies between the model results and satellite datasets are rather small compared with the differences between the two remote sensor-based datasets. The present-day global mean optical depth for each type of aerosol is compared with a large multi-model database. The model results are found to be consistent with the multimodel dataset for total aerosol, even if the sulfate content is slightly higher than the multi-model median. The modelcalculated stratospheric ozone distribution is also found to reproduce most of the features of a well-established satellite-based climatology.

The past negative stratospheric ozone trends, most apparent in the CFC-induced decline in polar ozone 
decrease between the 1970s and 1990s, is properly reproduced and results in a negative climate forcing culminating at $-0.15 \mathrm{~W} \mathrm{~m}^{-2}$ in the $1990 \mathrm{~s}$. In the meantime, the tropospheric ozone burden increases due to rising fossil-fuel consumption and generates a positive climate forcing peaking at $0.41 \mathrm{~W} \mathrm{~m}^{-2}$, according to our model computations. The future evolution of ozone strongly depends on the RCP scenario considered. In RCP4.5 and RCP6.0, the evolutions of both stratospheric and tropospheric ozone generate relatively weak radiative forcing changes until 2060-2070 followed by a $30 \%$ decrease in radiative forcing (in relative values) by 2100 . In contrast, RCP8.5 and RCP2.6 model projections exhibit strongly different ozone radiative forcing trajectories. In the RCP2.6 scenario, both effects (stratospheric ozone, a negative forcing, and tropospheric ozone, a positive forcing) decline towards 1950s values while they both get stronger in the RCP8.5 scenario. Whereas the tropospheric ozone radiative forcing is correlated to the tropospheric ozone burden increase in the past and the future, the evolution of the stratospheric ozone forcing may be more correlated with the evolution of ozone content in the tropical lower stratosphere than with the stratospheric ozone burden.

Over the twentieth century, the evolution of the total aerosol burden is characterized (according to the emission dataset available) by a strong increase after World War II until the middle of the 1980 s followed by a stabilization during the last decade due to the strong decrease in sulfates in OECD countries since the 1970s. According to the RCP scenarios, after peaking around 2010, the aerosol content is projected to decline strongly during the twenty-first century either monotonically for RCP8.5, 4.5 and 2.6 or after peaking around 2050 for the RCP6.0 scenario. This common feature in the emission scenario is strongly different from the SRES trajectories used for the previous IPCC report. As a consequence the relative importance of the total cooling effect of aerosols becomes weaker throughout the twenty-first century compared with the positive forcing of GHG. This is due in particular to the inclusion of black carbon positive forcing during the first half of the century followed by the emission decline during the second half of the century.

Nevertheless, both surface ozone and aerosol contents show very different regional features depending on the future scenario considered. These regional differences are of crucial interest regarding the impact of surface ozone on vegetation or on air quality index and regarding regional aerosol-driven climate feedbacks.

Acknowledgments Computer time was provided by the CCRT/ GENCI computer center of the CEA. This research was supported by CNRS, via the INSU-LEFE French Program under the project MISTERRE and by the PRIMEQUAL project called Salut'air. The IPSLCM5 model development and the IPSL-CM5 simulations were performed by the "IPSL Climate Modeling Center'. The authors are thankful for their technical help in carrying the INCA simulations out. The authors are grateful to the LATMOS (J. Hadji-Lazaro, M. George, C. Clerbaux) and the ULB (P.F. Coheur, D. Hurtmans) IASI teams for the availability of the IASI ozone retrievals and their support in the data analysis. They also acknowledge the Ether French atmospheric database (http://ether.ipsl.jussieu.fr) for providing the IASI data and CNES for financial support. The TES data were obtained from the NASA Langley Research Center Atmospheric Science Data Center. The authors acknowledge the TES-NASA team for the availability of ozone level 2 retrievals and the TES Pis (A. Eldering, J. Worden, R. Beer) from the Jet Propulsion Laboratory, NASA.

Open Access This article is distributed under the terms of the Creative Commons Attribution License which permits any use, distribution, and reproduction in any medium, provided the original author(s) and the source are credited.

\section{References}

Aghedo AM, Bowman KW, Worden HM, Kulawik SS, Shindell DT, Lamarque JF, Faluvegi G, Parrington M, Jones DBA, Rast S (2011) The vertical distribution of ozone instantaneous radiative forcing from satellite and chemistry climate models. J Geophys Res 116:D01305. doi:10.1029/2010JD014243

Austin J et al (2010a) The decline and recovery of total column ozone using a multi-model time series analysis. J Geophys Res 115: D00M10. doi:10.1029/2010JD013857

Austin J et al (2010b) Chemistry-climate model simulations of spring Antarctic ozone. J Geophys Res 115:D00M11. doi:10.1029/2009 JD013577

Balkanski Y (2011) L'Influence des Aérosols sur le Climat-Thèse d'Habilitation à Diriger des Recherches. Université Versailles Saint Quentin, France

Bellouin N, Rae J, Jones A, Johnson C, Haywood J, Boucher O (2011) Aerosol forcing in the Climate Model Intercomparison Project (CMIP5) simulations by HadGEM2-ES and the role of ammonium nitrate. J Geophys Res 116:D20206. doi:10.1029/2011 JD016074

Boucher O, Lohmann U (1995) The sulfate - $\mathrm{CCN}$ - cloud albedo effect-a sensitivity study with two general circulation models. Tellus Ser B 47:281-300

Boucher O, Pham M (2002) History of sulfate aerosol radiative forcing. Geophys Res Lett 29(9). doi:10.1029/2001GL0140148

Bowman KW, Steck T, Worden HM, Worden J, Clough S, Rodgers C (2002) Capturing time and vertical variability of tropospheric ozone: a study using TES nadir retrievals. J Geophys Res 107(D23):4723. doi:10.1029/2002JD002150

Bowman KWEt et al (2006) Tropospheric emission spectrometer: retrieval method and error analysis. IEEE Trans Geosci Remote Sens 44(5):1297-1307. doi:10.1109/TGRS.2006.871234

Boxe CS, Worden JR, Bowman KW, Kulawik SS, Neu JL, Ford WC, Osterman GB, Herman RL, Eldering A, Tarasick DW, Thompson AM, Doughty DC, Hoffmann MR, Oltmans SJ (2010) Validation of northern latitude tropospheric emission spectrometer stare ozone profiles with ARC-IONS sondes during ARCTAS: sensitivity, bias and error analysis. Atmos Chem Phys 10I(20):9901-9914. doi:10.5194/acp-10-9901-2010

Boynard A, Clerbaux C, Coheur P-F, Hurtmans D, Turquety S, George M, Hadji-Lazaro J, Keim C, Meyer-Arnek J (2009) Measurements of total and tropospheric ozone from IASI: 
comparison with correlative satellite, ground-based and ozonesonde observations. Atmos Chem Phys 9:6255-6271. doi: 10.5194/acp-9-6255-2009

Brient F, Bony S (2012) Interpretation of the positive low-cloud feedback predicted by a climate model under global warming. Clim Dyn. doi:10.1007/s00382-011-1279-7

Chin M, Ginoux P, Kinne S, Holben BN, Duncan BN, Martin RV, Logan JA, Higurashi A, Nakajima T (2002) Tropospheric aerosol optical thickness from the GOCART model and comparisons with satellite and sun photometer measurements. J Atmos Sci 59:461-483

Chung SH, Seinfeld JH (2002) Global distribution and climate forcing of carbonaceous aerosols. J Geophys Res 107. doi:10.1029/ 2001JD00397

Cionni I, Eyring V, Lamarque JF, Randel WJ, Stevenson DS, Wu F, Bodeker GE, Shepherd TG, Shindell DT, Waugh DW (2011) Ozone database in support of CMIP5 simulations: results and corresponding radiative forcing. Atmos Chem Phys 11:1126711292. doi:10.5194/acp-11-11267-2011

Clarke L, Edmonds J, Jacoby H, Pitcher H, Reilly J, Richels R (2007) Scenarios of greenhouse gas emissions and atmospheric concentrations. Sub-report 2.1A of synthesis and assessment product 2.1 by the US climate change science program and the subcommittee on global change research. Department of Energy, Office of Biological and Environmental Research, Washington, DC, USA, vol 7, 154 pp

Coheur P-F, Barret B, Turquety S, Hurtmans D, Hadji-Lazaro J, Clerbaux C (2005) Retrieval and characterization of ozone vertical profiles from the IMG nadir high-resolution thermal infrared remote sounder. J Geophys Res 110:D24303. doi: 10.1029/2005JD005845

Cooke WF, Wilson JJN (1996) A global black carbon aerosol model. J Geophys Res 101:19395-19409

Déandreis C (2008) Impact des aerosols anthropiques sur le climat present et future, Thèse de Doctorat de l'Université Pierre et Marie Curie, Paris VI

Déandreis C, Balkanski Y, Dufresne JL, Cozic A (2011) Radiative forcing estimates in coupled climate-chemistry models with emphasis on the role of the temporal variability. Atmos Chem Phys Discuss 11:24313-24364. doi:10.5194/acpd-11-243132011

Dentener F, Stevenson D, Cofala J, Mechler R, Amann M, Bergamaschi P, Raes F, Derwent R (2005) The impact of air pollutant and methane emission controls on tropospheric ozone and radiative forcing: CTM calculations for the period 1990-2030. Atmos Chem Phys 5:1731-1755. doi:10.5194/acp5-1731-2005

Dentener F et al (2006a) Global atmospheric environment for the next generation. Environ Sci Technol 40:3586-3594

Dentener F, Kinne S, Bond T, Boucher O, Cofala J, Generoso S, Ginoux P, Gong S, Hoelzemann J, Ito A, Marelli L, Penner J, Putaud J-P, Textor C, Schulz M, van der Werf G, Wilson J (2006b) Emissions of primary aerosol and precursor gases in the years 2000 and 1750 -prescribed data-sets for AeroCom. Atmos Chem Phys 6:4321-4344

Dufour G, Eremenko M, Griesfeller A, Barret B, LeFlochmoën E, Clerbaux C, Hadji-Lazaro J, Coheur P-F, Hurtmans D (2011) Validation of three different scientific ozone products retrieved from IASI spectra using ozonesondes. Atmos Meas Tech Discuss 4:5425-5479. doi:10.5194/amtd-4-5425-2011

Dufresne JL et al The IPSL-CM5A Earth System Model: general description and climate change projections, submitted to this issue

Dufresne J-L, Quaas J, Boucher O, Denvil S, Fairhead L (2005) Contrasts in the effects on climate of anthropogenic sulfate aerosols between the 20th and the 21st century. Geophys Res Lett 32:L21703. doi:10.1029/2005GL023619
Ellingsen K, Gauss M, Van Dingenen R, Dentener FJ, Emberson L, Fiore AM, Schultz MG, Stevenson DS, Ashmore MR, Atherton CS, Bergmann DJ, Bey I, Butler T, Drevet J, Eskes H, Hauglustaine DA, Isaksen ISA, Horowitz LW, Krol M, Lamarque JF, Lawrence MG, van Noije T, Pyle J, Rast S, Rodriguez J, Savage N, Strahan S, Sudo K, Szopa S, Wild O (2008) Global ozone and air quality: a multi-model assessment of risks to human health and crops. ACPD 8:2163-2223. SRef-ID: 16807375/acpd/2008-8-2163

Eyring V, Harris NRP, Rex M, Shepherd TG, Fahey DW, Amanatidis GT, Austin J, Chipperfield MP, Dameris M, De PM, Forster F, Gettelman A, Graf HF, Nagashima T, Newman PA, Pawson S, Prather MJ, Pyle JA, Salawitch RJ, Santer BD, Waugh DW (2005) A strategy for process-oriented validation of coupled chemistry-climate models. Bull Am Meteorol Soc 86:1117-1133

Eyring V, Butchart N, Waugh DW, Akiyoshi H, Austin J, Bekki S, Bodeker GE, Boville BA, Brühl C, Chipperfield MP, Cordero E, Dameris M, Deushi M, Fioletov VE, Frith SM, Garcia RR, Gettelman A, Giorgetta MA, Grewe V, Jourdain L, Kinnison DE, Mancini E, Manzini E, Marchand M, Marsh DR, Nagashima T, Newman PA, Nielsen JE, Pawson S, Pitari G, Plummer DA, Rozanov E, Schraner M, Shepherd TG, Shibata K, Stolarski RS, Struthers H, Tian W, Yoshiki M (2006) Assessment of temperature, trace species and ozone in chemistry-climate model simulations of the recent past. J Geophys Res 111:D22308. doi: 10.1029/2006JD007327

Eyring V, Waugh DW, Bodeker GE, Cordero E, Akiyoshi H, Austin J, Beagley SR, Boville B, Braesicke P, Brühl C, Butchart N, Chipperfield MP, Dameris M, Deckert R, Deushi M, Frith SM, Garcia RR, Gettelman A, Giorgetta M, Kinnison DE, Mancini E, Manzini E, Marsh DR, Matthes S, Nagashima T, Newman PA, Nielsen JE, Pawson S, Pitari G, Plummer DA, Rozanov E, Schraner M, Scinocca JF, Semeniuk K, Shepherd TG, Shibata K, Steil B, Stolarski R, Tian W, Yoshiki M (2007) Multimodel projections of stratospheric ozone in the 21 st century. J Geophys Res 112:D16303. doi:10.1029/2006JD008332

Eyring V et al (2010a) Sensitivity of 21st century stratospheric ozone to greenhouse gas scenarios. Geophys Res Lett 37:L16807. doi: 10.1029/2010GL044443

Eyring V et al (2010b) Multi-model assessment of stratospheric ozone return dates and ozone recovery in CCMVal-2 models. Atmos Chem Phys 10:9451-9472. doi:10.5194/acp-10-9451-2010

Fiore AM, Dentener FJ, Wild O, Cuvelier C, Schultz MG, Hess P, Textor C, Schulz M, Doherty R, Horowitz LW, MacKenzie IA, Sanderson MG, Shindell DT, Stevenson DS, Szopa S, Van Dingenen R, Zeng G, Atherton C, Bergmann D, Bey I, Carmichael G, Duncan BN, Faluvegi G, Folberth G, Gauss M, Gong S, Hauglustaine D, Holloway T, Isaksen ISA, Jacob DJ, Jonson JE, Kaminski JW, Keating TJ, Lupu A, Marmer E, Montanaro V, Park R, Pitari G, Pringle KJ, Pyle JA, Schroeder S, Vivanco MG, Wind P, Wojcik G, Wu S, Zuber A (2009) Multi-model estimates of intercontinental source-receptor relationships for ozone pollution. J Geophys Res 114:D04301. doi:10.1029/2008JD010816

Flanner MG, Zender CS, Hess PG, Mahowald NM, Painter TH, Ramanathan V, Rasch PJ (2009) Springtime warming and reduced snow cover from carbonaceous particles. Atmos Chem Phys 9:2481-2497. doi:10.5194/acp-9-2481-2009

Folberth GA, Hauglustaine DA, Lathière J, Brocheton F (2006) Interactive chemistry in the Laboratoire de Météorologie Dynamique general circulation model: model description and impact analysis of biogenic hydrocarbons on tropospheric chemistry Atmos Chem Phys 6:2273-2319. www.atmos-chem-phys.net/ 6/2273/2006/

Forster PMF (1999) Radiative forcing due to stratospheric ozone changes 1979-1997, using updated trend estimates. J Geophys Res 104:24395-24399 
Forster P et al (2007) In: Solomon S et al (ed) Climate change 2007: the physical science basis. Cambridge University Press, Cambridge, pp 129-234

Fouquart Y, Bonnel B (1980) Computations of solar heating of the Earth's atmosphere: a new parameterization. Beitr Phys Atmos 53:35-63

Fujino J, Nair R, Kainuma M, Masui T, Matsuoka Y (2006) Multi-gas mitigation analysis on stabilization scenarios using AIM global model. Multigas mitigation and climate policy. Energy J Special Issue

Gauss M et al (2006) (2006), Radiative forcing since preindustrial times due to ozone change in the troposphere and the lower stratosphere. Atmos Chem Phys 6:575-599

Gettelman A et al (2009a) Multimodel assessment of the upper troposphere and lower stratosphere: tropics and global trends. J Geophys Res 115:D00M08. doi:10.1029/2009JD013638

Gettelman A et al (2009b) The tropical tropopause layer 1960-2100. Atmos Chem Phys 9:1621-1637

Hansen J et al (2005) Efficacy of climate forcings. J Geophys Res 110:D18104. doi:10.1029/2005JD005776

Hauglustaine DA, Hourdin F, Jourdain L, Filiberti M-A, Walters S, Lamarque J-F, Holland EA (2004) Interactive chemistry in the Laboratoire de Meteorologie Dynamique general circulation model: description and background tropospheric chemistry evaluation. J Geophys Res 109:D04314. doi:10.1029/2003JD003957

Hegglin MI et al (2010) Multimodel assessment of the upper troposphere and lower stratosphere: extratropics. J Geophys Res 115:D00M09. doi:10.1029/2010JD013884

Hijioka Y, Matsuoka Y, Nishimoto H, Masui M, Kainuma M (2008) Global GHG emissions scenarios under GHG concentration stabilization targets. J Glob Environ Eng 13:97-108

Hourdin F, Musat I, Bony S, Braconnot P, Codron F, Dufresne J-L, Fairhead L, Filiberti M-A, Friedlingstein P, Grandpeix J-Y, Krinner G, LeVan P, Li Z-X, Lott F (2006) The LMDZ4 general circulation model: climate performance and sensitivity to parametrized physics with emphasis on tropical convection. Clim Dyn 27:787-813. doi:10.1007/s00382-006-0158-0

Hourdin F, Grandpeix J-Y, Rio C, Bony S, Jam A, Rochetin N, Fairhead L, Idelkadi A, Musat I, Dufresne J-L et al The LMDZ5NP climate model: a breakthrough in the parametrization of boundary layer, clouds and convection, submitted to this issue

Intergovernmental Panel on Climate Change (IPCC) (1990) Report on Climate change by Working Group I. In: Houghton JT, Jenkins GJ, Ephraums JJ (eds) Cambridge University Press, Cambridge, Great Britain, New York, USA and Melbourne, Australia

Intergovernmental Panel on Climate Change (IPCC) (2001) Climate change 2001: the scientific basis: contribution of Working Group 1 to the third assessment report of the intergovernmental panel on climate change. In: Houghton JT et al (ed) Cambridge University Press, New York, $881 \mathrm{pp}$

IPCC (2007) Summary for policymakers. In: Solomon S, Qin D, Manning M, Chen Z, Marquis M, Averyt KB, Tignor M, Miller HL (eds) Climate change 2007: the physical science basis. Contribution of Working Group I to the Fourth Assessment Report of the Intergovernmental Panel on Climate Change. Cambridge University Press, Cambridge, United Kingdom and New York, NY, USA

Irshad R, Grainger RG, Peters DM, McPheat RA, Smith KM, Thomas G (2009) Laboratory measurements of the optical properties of sea salt aerosol. Atmos Chem Phys 9:221-230

Joseph JH, Wiscombe WJ, Weinman JA (1996) The delta-Eddington approximation for radiative flux transfer. J Atmos Sci 33:24522459

Jourdain L, Hauglustaine DA (2001) The global distribution of lightning NOx simulated on-line in a general circulation model. Phys Chem Earth 26:585-591
Jourdain L, Bekki S, Lott F, Lefevre F (2008) The coupled chemistryclimate model LMDz-REPROBUS: description and evaluation of a transient simulation of the period 1980-1999. Ann Geophys 26:1391-1413

Kanamitsu M, Ebisuzaki W, Woollen J, Yang SK et al (2002) NCEP-DOE AMIP-II reanalysis (R-2). Bull Amer Meteoro Soc 83:1631-1643

Keim C, Eremenko M, Orphal J, Dufour G, Flaud J-M, Höpfner M, Boynard A, Clerbaux C, Payan S, Coheur P-F, Hurtmans D, Claude H, Dier H, Johnson B, Kelder H, Kivi R, Koide T, López Bartolomé M, Lambkin K, Moore D, Schmidlin FJ, Stübi R (2009) Tropospheric ozone from IASI: comparison of different inversion algorithms and validation with ozone sondes in the northern middle latitudes. Atmos Chem Phys 9:9329-9347. doi: 10.5194/acp-9-9329-2009

Kinne S, Schulz M, Textor C, Guibert S, Balkanski Y, Bauer SE, Berntsen T, Berglen TF, Boucher O, Chin M, Collins W, Dentener F, Diehl T, Easter R, Feichter J, Fillmore D, Ghan S, Ginoux P, Gong S, Grini A, Hendricks J, Herzog M, Horowitz L, Isaksen I, Iversen T, Kirkevåg A, Kloster S, Koch D, Kristjansson JE, Krol M, Lauer A, Lamarque JF, Lesins G, Liu X, Lohmann U, Montanaro V, Myhre G, Penner J, Pitari G, Reddy S, Seland $\varnothing$, Stier P, Takemura T, Tie X (2006) An AeroCom initial assessment optical properties in aerosol component modules of global models. Atmos Chem Phys 6:1815-1834

Krinner G et al (2005) A dynamic global vegetation model for studies of the coupled atmosphere-biosphere system. Glob Biogeochem Cycles 19(1):GB1015. doi:10.1029/2003GB002199

Kulawik SS, Worden J, Eldering A, Bowman K, Gunson M, Osterman GB, Zhang L, Clough S, Shepard MW, Beer R (2006) Implementation of cloud retrievals for Tropospheric Emission Spectrometer (TES) atmospheric retrievals: 1. Description and characterization of errors on trace gas retrievals. J Geophys Res 111:D24204. doi:10.1029/2005JD006733

Lamarque J-F, Bond TC, Eyring V, Granier C, Heil A, Klimont Z, Lee D, Liousse C, Mieville A, Owen B, Schultz MG, Shindell D, Smith SJ, Stehfest E, Van Aardenne J, Cooper OR, Kainuma M, Mahowald N, McConnell JR, Naik V, Riahi K, van Vuuren DP (2010) Historical (1850-2000) gridded anthropogenic and biomass burning emissions of reactive gases and aerosols: methodology and application. Atmos Chem Phys 10:7017-7039

Lamarque JF, Kyle GP, Meinshausen M, Riahi K, Smith SJ, van Vuuren DP, Conley AJ, Vitt F (2011) Global and regional evolution of short-lived radiatively-active gases and aerosols in the representative concentration pathways. Clim Chang 109(1-2):191-212. doi:10.1007/s10584-011-0155-0

Lathière J, Hauglustaine DA, Friend AD, De Noblet-Ducoudre N, Viovy N, Folberth GA (2006) Impact of climate variability and land use changes on global biogenic volatile organic compound emissions. Atmos Chem Phys 6:2129-2146. www.atmos-chemphys.net/6/2129/2006/

Lefevre F, Brasseur GP, Folkins I, Smith AK, Simon P (1994) Chemistry of the 1991-1992 stratospheric winter: three-dimensional model simulations. J Geophys Res 199:8183-8195

Lefevre F, Figarol F, Carslaw KS, Peter T (1998) The 1997 Arctic ozone depletion quantified from three-dimensional model simulations. Geophys Res Lett 25(13):2425-2428

Lenton A, Codron F, Bopp L, Metzl N, Cadule P, Tagliabue A, Le Sommer J (2009) Stratospheric ozone depletion reduces ocean carbon uptake and enhances ocean acidification. Geophys Res Lett 36:L12606. doi:10.1029/2009GL038227

Li D, Shine KP (1995) A 4-D ozone climatology for UGAMP models, UGAMP internal report. UK Univ. Global Atmos. Model, Programme

Lott F, Fairhead L, Hourdin F, Levan P (2005) The stratospheric version of LMDz: dynamical climatologies, arctic oscillation, and impact on the surface climate. Clim Dyn 25:851-868 
Madronich S, Flocke S (1998) The role of solar radiation in atmospheric chemistry. In: Boule P (ed) Handbook of environmental chemistry. Springer, Heidelberg, pp 1-26

Marti O, Braconnot P, Bellier J, Benshila R, Bony S, Brockmann P, Cadule P, Caubel A, Denvil S, Dufresne J-L, Fairhead L, Filiberti M-A, Foujols M-A, Fichefet T, Friedlingstein P, Goosse H, Grandpeix J-Y, Hourdin F, Krinner G, Lévy C, Madec G, Musat I, de Noblet N, Polcher J, Talandier C (2005) The new IPSL climate system model: IPSL-CM4. Institut Pierre Simon Laplace, Paris, p 84

Martin ST, Schlenker JC, Malinowski A, Hung H-M, Rudich Y (2003) Crystallization of atmospheric sulfate-nitrate-ammonium particles. Geophys Res Lett 30(21):2102. doi:10.1029/2003 GL017930

Meehl GA, Stocker TF, Collins WD, Friedlingstein P, Gaye AT, Gregory JM, Kitoh A, Knutti R, Murphy JM, Noda A, Raper SCB, Watterson IG, Weaver AJ, Zhao Z-C (2007) Global climate projections. In: Solomon S, Qin D, Manning M, Chen Z, Marquis M, Averyt KB, Tignor M, Miller HL (eds) Climate change 2007: the physical science basis. Contribution of Working Group I to the fourth assessment report of the intergovernmental panel on climate change. Cambridge University Press, Cambridge, United Kingdom and New York, NY, USA

Morcrette J-J, Fouquart Y (1986) The overlapping of cloud layers in shortwave radiation parameterizations. J Atmos Sci 43:321-328

Morgenstern $O$ et al (2010) Review of the formulation of present generation stratospheric chemistry-climate models and associated external forcings. J Geophys Res 115:D00M02. doi: 10.1029/2009JD013728

Moss RH, Edmonds JA, Hibbard K, Carter T, Emori S, Kainuma M, Kram T, Manning M, Meehl J, Mitchell J, Nakicenovic N, Riahi K, Rose S, Smith SJ, Stouffer R, Thomson AM, VanVuuren D, Weyant J, Wilbanks T (2010) Representative concentration pathways: a new approach to scenario development for the IPCC fifth assessment report. Nature 463:747-756

Nassar R, Logan JA, Worden HM, Megretskaia IA, Bowman KW, Osterman GB, Thompson AM, Tarasick DW, Austin S, Claude H, Dubey MK, Hocking WK, Johnson BJ, Joseph E, Merrill J, Morris GA, Newchurch M, Oltmans SJ, Posny F, Schmidlin FJ, Vômel H, Whiteman DN, Witte JC (2008) Validation of tropospheric emission spectrometer (TES) nadir ozone profiles using ozonesonde measurements. J Geophys Res 113:D15817. doi:10.1029/2007JD008819

Pham M, Boucher O, Hauglustaine D (2005) Changes in atmospheric sulfur burdens and concentrations and resulting radiative forcings under IPCC SRES emission scenarios for 1990-2100. J Geophys Res 110:D06112. doi:10.1029/2004JD005125

Pickering KE, Wang Y, Tao W-K, Price C, Müller J-F (1998) Vertical distributions of lightning NO for use in regional and global chemical transport models. Geophys Res Lett 103:31203-31216

Price C, Rind D (1992) A simple lightning parameterization for calculating global lightning distributions. J Geophys Res 97:9919-9933

Quaas J (2011) Global warming: the soot factor. Nature 471:456-457. doi: $10.1038 / 471456 \mathrm{a}$

Quaas J, Boucher O (2005) Constraining the first aerosol indirect radiative forcing in the LMDZ GCM using POLDER and MODIS satellite data. Geophys Res Lett 32:L17814. doi: 10.1029/2005GL023850

Quaas J, Boucher O, Bréon F-M (2004a) Aerosol indirect effects in POLDER satellite data and the Laboratoire de Meteorologie Dynamique- Zoom (LMDZ) general circulation model. J Geophys Res 109:D08205. doi:10.1029/2003JD004317

Quaas J, Boucher O, Dufresne J-L, Le Treut H (2004b) Impacts of greenhouse gases and aerosol direct and indirect effects on clouds and radiation in atmospheric GCM simulations of the
1930-1989 period. Clim Dyn 23:779-789. doi:10.1007/s00382004-0475-0

Rayner NA, Parker DE, Horton EB, Folland CK, Alexander LV, Rowell DP, Kent EC, Kaplan A (2003) Global analyses of sea surface temperature, sea ice, and night marine air temperature since the late nineteenth century. J Geophys Res 108(D14):4407. doi: 10.1029/2002JD002670

Reddy MS, Boucher O, Bellouin N, Schulz M, Balkanski Y, Dufresne J-L, Pham M (2005) Estimates of global multicomponent aerosol optical depth and direct radiative perturbation in the Laboratoire de Météorologie Dynamique general circulation model. J Geophys Res 110:D10S16. doi:10.1029/2004JD004757

Reidmiller DR, Fiore AM, Jaffe DA, Bergmann D, Cuvelier C, Dentener FJ, Duncan BN, Folberth G, Gauss M, Gong S, Hess P, Jonson JE, Keating T, Lupu A, Marmer E, Park R, Schultz MG, Shindell DT, Szopa S, Vivanco MG, Wild O, Zuber A (2009) The influence of foreign vs. North American emissions on surface ozone in the US. Atmos Chem Phys 9:5027-5042

Riahi K, Gruebler A, Nakicenovic N (2007) Scenarios of long-term socio-economic and environmental development under climate stabilization. Technol Forecast Soc Chang 74(7):887-935

Rodgers CD et al (2000) Inverse methods for atmospheric sounding: theory and practice. World Science, London

Sander SP et al (2006) JPL 2006: chemical kinetics and photochemical data for use in atmospheric studies, Eval. 15, JPL Publ. 06-2, Jet Propul. Lab., Pasadena

Schulz M (2007) Constraining model estimates of the aerosol radiative forcing. Thèse d'Habilitation à Diriger des Recherches, Université Pierre et Marie Curie, Paris VI

Schulz M, AeroCom team (2011) Typical aerosol properties as suggested by the AeroCom model ensemble median (in preparation for ACP)

Schulz M, Balkanski Y, Dulac F, Guelle W (1998) Role of aerosol size distribution and source location in a three-dimensional simulation of a Saharan dust episode tested against satellitederived optical thickness. J Geophys Res 103:10579-10592

Schulz M, Textor C, Kinne S, Balkanski Y, Bauer S, Berntsen T, Berglen T, Boucher O, Dentener F, Grini A, Guibert S, Iversen T, Koch D, Kirkevåg A, Liu X, Montanaro V, Myhre G, Penner J, Pitari G, Reddy S, Seland Ø, Stier P, Takemura T (2006) Radiative forcing by aerosols as derived from the AeroCom present-day and pre-industrial simulations. Atmos Chem Phys 6:5225-5246

Shindell DT, Faluvegi G, Bell N (2003) Preindustrial-to-present-day radiative forcing by tropospheric ozone from improved simulations with the GISS chemistry-climate GCM. Atmos Chem Phys 3:1675-1702

Sitch S, Cox PM, Collins WJ et al (2007) Indirect radiative forcing of climate change through ozone effects on the land-carbon sink. Nature 448:791-794. doi:10.1038/nature06059

Smith SJ, Wigley TML (2006) Multi-Gas forcing stabilization with the MiniCAM. Energy J (Special Issue \#3):373-391

Smith SJ, West JJ, Kyle P (2011) Economically consistent long-term scenarios for air pollutant emissions. Clim Chang 108(3):619-627. doi:10.1007/s10584-011-0219-1

Son S-W, Gerber EP, Perlwitz J, Polvani LM, Gillett NP, Seo K-H, Eyring V, Shepherd TG, Waugh D, Akiyoshi H, Austin J, Baumgaertner A, Bekki S et al (2010) The impact of stratospheric ozone on southern hemisphere circulation change: a multimodel assessment. J Geophys Res 115:D00M07. doi: 10.1029/2010JD014271

SPARC CCMVal (2010) SPARC report on the evaluation of chemistry-climate models. In: Eyring V, Shepherd TG, Waugh DW (eds) SPARC report no. 5, WCRP-132, WMO/TD-No. 1526 Stevenson DS, Dentener FJ, Schultz M, Ellingsen K, van Noije T, Zeng G, Amann M, Atherton CS, Bell N, Bergmann DJ, Bey I, 
Butler T, Cofala J, Collins WJ, Derwent RG, Doherty RM, Drevet J, Eskes H, Fiore A, Gauss M, Hauglustaine D, Horowitz L, Isaksen I, Krol M, Lamarque JF, Lawrence M, Montanaro V, Muller JF, Pitari G, Prather MJ, Pyle J, Rast S, Rodriguez J, Sanderson M, Savage N, Shindell D, Strahan S, Sudo K, Szopa S, Wild O (2006) Multi-model ensemble simulations of presentday and near-future tropospheric ozone. J Geophys Res 111: D08301. doi:10.1029/2005JD006338

Szopa S, Hauglustaine D, Vautard R, Menut L (2006) Evolution of the tropospheric composition in 2030: impact on European air quality. Geophys Res Lett 33:L14805. doi:10.1029/2006GL025860

Textor C, Schulz M, Kinne S, Guibert S, Bauer S, Berntsen T, Berglen T, Boucher O, Chin M, Dentener F, Diehl T, Feichter H, Fillmore D, Ghan S, Ginoux P, Gong S, Grini A, Hendricks J, Horrowitz L, Isaksen I, Iversen T, Koch D, Krol M, Lauer A, Lamarque JF, Liu X, Montanaro V, Myhre G, Penner J, Pitari G, Reddy S, Seland O, Stier P, Takemura T, Tie X (2006) Analysis and quantification of the diversities of aerosol life cycles within AeroCom. Atmos Chem Phys 6:1777-1813

Thomson AM, Calvin KV, Smith SJ, Kyle GP, Volke A, Patel P, Delgado-Arias S, Bond-Lamberty B, Wise MA, Clarke LE, Edmonds JA (2011) RCP4.5: a pathway for stabilization of radiative forcing by 2100 climatic change. doi:10.1007/ s10584-011-0151-4 van Vuuren D, den Elzen M, Lucas P, Eickhout B, Strengers B, van Ruijven B, Wonink S, van Houdt R (2007) Stabilizing greenhouse gas concentrations at low levels: an assessment of reduction strategies and costs. Clim Chang. doi:10.1007/s/ 10584-006-9172-9

Voldoire A, Sanchez-Gomez E, Salas y Mélia D, Decharme B, Cassou C, Sénési S, Valcke S, Beau I, Alias A, Chevallier M, Déqué M, Deshayes J, Douville H, Fernandez E, Madec G, Maisonnave E, Moine M-P, Planton S, Saint-Martin D, Szopa S, Tyteca S, Alkama R, Belamari S, Braun A, Coquart L, Chauvin F (2012) The CNRM-CM5.1 global climate model: description and basic évaluation. Clim Dyn. doi:10.1007/s00382-011-1259-y

WMO (2007) Scientific assessment of ozone depletion: 2006, World Meteorological Organization. Global Ozone Research and Monitoring Project, Report 50. Geneva, 572 pp

WMO (2011) Scientific assessment of stratospheric ozone: 2010. World Meteorological Organization, Global Ozone Research and Monitoring Project, Report 52. Geneva 438 pp

Worden JS, Kulawik SS, Shepard M, Clough S, Worden H, Bowman K, Goldman A (2004) Predicted errors of tropospheric emission spectrometer nadir retrievals from spectral window selection. J Geophys Res 109:D09308. doi:10.1029/2004JD004522 